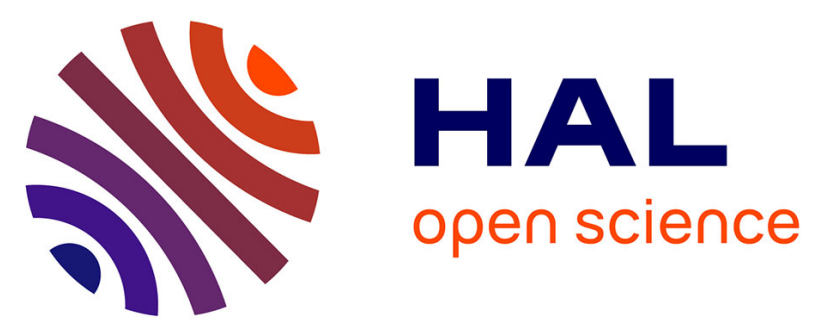

\title{
Precambrian protoliths and Early Paleozoic magmatism in the French Massif Central: U-Pb data and the North Gondwana connection in the west European Variscan belt
}

Jérémie Melleton, Alain Cocherie, Michel Faure, Philippe Rossi

\section{To cite this version:}

Jérémie Melleton, Alain Cocherie, Michel Faure, Philippe Rossi. Precambrian protoliths and Early Paleozoic magmatism in the French Massif Central: U-Pb data and the North Gondwana connection in the west European Variscan belt. Gondwana Research, 2010, 17, pp.13-25. 10.1016/j.gr.2009.05.007 . insu-00442947

\section{HAL Id: insu-00442947 https://hal-insu.archives-ouvertes.fr/insu-00442947}

Submitted on 5 Jan 2010

HAL is a multi-disciplinary open access archive for the deposit and dissemination of scientific research documents, whether they are published or not. The documents may come from teaching and research institutions in France or abroad, or from public or private research centers.
L'archive ouverte pluridisciplinaire HAL, est destinée au dépôt et à la diffusion de documents scientifiques de niveau recherche, publiés ou non, émanant des établissements d'enseignement et de recherche français ou étrangers, des laboratoires publics ou privés. 


\title{
Precambrian protoliths and Early Paleozoic magmatism in the French Massif Central: U-Pb data and the North Gondwana connection in the west European Variscan belt
}

\author{
Jérémie Melleton $^{\underline{a}, \underline{b}}$, Alain Cocherie ${ }^{\underline{b}}$, Michel Faure ${ }^{\underline{a}}$ and Philippe Rossi $^{\underline{b}}$
}

${ }^{a}$ Université d'Orléans, CNRS/INSU, Université François Rabelais - Tours, Institut des Sciences de la Terre d'Orléans (ISTO), UMR 6113, Campus Géosciences, 1A rue de la Férollerie, 45071 Orléans Cedex 2, France

${ }^{\mathrm{b}}$ Bureau de Recherches Géologiques et Minières (BRGM), BP 36009, 45060 Orléans Cedex 2, France

\begin{abstract}
$\mathrm{U}-\mathrm{Pb}$ geochronological data were collected on zircon by LA-MC-ICP-MS on orthogneiss and paragneiss from the Limousin area in the French Massif Central (FMC), in order to investigate the connection between the west European Variscan belt and the northern margin of Gondwana. Fifteen samples were collected in the four main tectonostratigraphic units of the FMC, namely: the Para-Autochthonous Unit, the Lower Gneiss Unit (LGU), the Upper Gneiss Unit (UGU) and the Thiviers-Payzac Unit. Orthogneiss yield intrusion age between $521 \pm 7$ and $446 \pm 6 \mathrm{Ma}$. Considering all the results from both magmatic and metasedimentary samples, two peaks at 531 and $473 \mathrm{Ma}$ are recognized. Rifting processes taking place along the North Gondwana margin during the Lower Paleozoic went on until the end of the Ordovician, as suggested by the magmatic event recorded around $450 \mathrm{Ma}$.
\end{abstract}

Several maximum depositional ages were ascertained in the metasedimentary formations of the FMC, as determined by the youngest detected detrital zircon crystal, ranging from $604 \pm 16 \mathrm{Ma}$ for metasediments of the Para-Autochthonous unit, $573 \pm 12 \mathrm{Ma}$ for the LGU, $564 \pm 9$ Ma for the Thiviers-Payzac Unit, and $523 \pm 4$ Ma in the UGU. Minimum depositional ages are given by magmatic emplacement ages obtained in the crosscutting orthogneiss. There is some evidence for a decrease of this maximum age upwards in the tectonostratigraphy. Detrital zircon in metasedimentary formations and inherited zircon in orthogneiss display a wide spectrum of ages with significant peaks at around $590 \mathrm{Ma}$ and 
$560 \mathrm{Ma}$. Archean, Paleoproterozoic and Neoproterozoic detrital zircons suggest a West African craton source of the sedimentation. The large amount of Neoproterozoic and Lower Paleozoic ages obtained in this study suggests that these periods played a significant role in the continental crustal growth history of Western Europe.

Keywords: North Gondwana margin; French Massif Central; Variscan orogeny; Zircon inheritance; Zircon LA-MC-ICP-MS dating; Cambro-Ordovician magmatism

\section{Introduction}

Extending for more than $8000 \mathrm{~km}$ from the Appalachians to the Caucasus, the Variscan Belt results from the Paleozoic convergence and collision between two continents, Gondwana in the South and Laurussia in the North, and several intervening microcontinents (e.g. [Matte, 1986] and [Matte, 1991]). The French Massif Central (FMC) is one of the largest coherent exposures of the Variscan belt in west Europa, and it is generally attributed to the North Gondwana margin, deformed and metamorphosed during the Paleozoic. Obscured by these Variscan tectonic and metamorphic events, the pre-Variscan evolution of the FMC remains more speculative. In Western Europe, the Variscan Belt lacks of a pre-orogenic cratonic igneous or metamorphic basement. In the Southern part of the FMC, a thick metapelitemetagrauwacke succession from Neoproterozoic to Ordovician age is well exposed, but there is a large uncertainty about the existence, the nature and the age of its underlying basement. In such orogens where the cratonic basement is not documented, the presence of inherited zircons in magmatic rocks or detrital zircons in sedimentary rocks can provide constraints on the age and the nature of a hypothetic pre-existing basement.

It is acknowledged that between 75 and $80 \%$ of the continental juvenile crust was extracted from the mantle during the Archean and the Paleoproterozoic (e.g. Condie, 1998, see also Condie et al., 2009). However, Rino et al. (2008), who sampled zircons from river mouth sediments of major rivers around the globe, came out with a different model for crustal growth and proposed that the Neoproterozoic (Grenvillian) and Pan-African were significant periods in Earth history for juvenile crustal growth. The Variscan orogen was mainly edified through crustal recycling, and only a small amount of juvenile crust is involved in the belt (Simien, 1998). In this context, investigations on protoliths are important, in order to understand the pre- and syn-orogenic processes, but also to constrain the timing of the West European continental crust formation. 
The history of the west European continental crustal accretion remains to be better constrained. Ziegler (1986) argued for the accretion of a mosaic of cratons built between $1.1 \mathrm{Ga}$ and $300 \mathrm{Ma}$. But direct evidence is lacking and further works dismissed this interpretation. Indeed, Archean and Paleoproterozoic U-Pb zircon ages are known in gneiss from the north Armorican domain ([Calvez and Vidal, 1978] and [Samson and D'Lemos, 1998]), in the deep crust of the Bay of Biscay (Gascogne Gulf; Guerrot et al., 1989), in Iberia (Fernández-Suárez et al., 2000), in the Western FMC (Limousin) (Lafon, 1986), and in Pyrenees (Cocherie et al., 2005). Moreover, Gebauer et al. (1989) established the presence of significant Archean to Neoproterozoic detrital components in Paleozoic sedimentary rocks in the Southern FMC (Montagne Noire). In South Brittany, Peucat et al. (1988) showed two important events at 2.7 Ga and $600 \mathrm{Ma}$. From Nd isotopic studies, Liew and Hofmann (1988) and Simien (1998) argued for a main event of continental crust accretion at the end of the Paleoproterozoic. Several studies also highlighted the importance of Early Paleozoic events ([Cocherie et al., 2005] and [Alexandre, 2007]).

Detrital zircon $\mathrm{U}-\mathrm{Pb}$ geochronology is a powerful tool to determine the maximum time of sedimentation of metamorphosed clastic sediments, to characterize potential provenance areas for the sediment and consequently to assess paleogeographic models. Zircon in magmatic rocks can have several origins. Generally, bulk of zircon in magmatic rocks is related to crystallization of the magma but its high resistance to episodic partial or full resetting of the $\mathrm{U}-\mathrm{Pb}$ isotopic system allows the conservation of inherited domains. The first provenance can be inherited zircon from the protolith, preserved during the partial melting episode, and by comparison with obtained ages in surrounded paraderived formations, gives information about the protolith of the magmatic rock. A second possibility can be the "contamination" by zircon of the country rocks scavenged during the ascent and emplacement of the magma. In this case, the nature of the underlying basement can be investigated. The improvement of in situ dating methods allows investigation in order to improve the knowledge of protolith ages and inheritances in the Variscan Belt. In this article, we report $\mathrm{U}-\mathrm{Pb}$ data on zircon by laser ablation-multicollector inductively coupled plasma mass spectrometry (LA-MC-ICP-MS) to revisit the geochronology of the Limousin area in the French Massif Central. The age of magmatic protoliths of orthogneiss are derived as well as the age spectra of inherited and detrital zircons in orthogneiss and paragneiss. The data provide an improved understanding of the pre-Variscan evolution of the French Massif Central and lead to a discussion on the link between microcontinents involved in the Variscan belt and the northern Gondwana margin. 


\section{Geological setting}

It is now widely accepted that the structure of the FMC is a stack of metamorphic nappes with a dominantly top-to-South displacement ([Ledru et al., 1989] and [Faure et al., 2005] and references therein). The Limousin area represents the north-western part of the FMC. There, from bottom to top, 4 main tectonics units are distinguished (Fig. 1 and Fig. 2; [Santallier, 1981] and [Floc, 1983]). i) The Para-Autochthonous Unit consists of a thick metapelitemetagrauwacke series with some quartzite beds and volcanic rocks. A Neoproterozoic to Ordovician age is generally accepted for these series; ii) The Lower Gneiss Unit (LGU) contains numerous Early Cambrian and Early Ordovician alkaline granitoids intruding paragneiss host rocks; iii) The Upper Gneiss Unit (UGU) is composed of migmatitic paragneiss enclosing eclogite boudins, mafic and felsic granulites lenses, and orthogneiss; iv) The Thiviers-Payzac Unit is made up of Cambrian metagraywakes, rhyolites and quartzites intruded by Ordovician granites. All these units are intruded by Late Devonian and Carboniferous syn to post kinematic granitoids.

Two HT metamorphic events dated as Middle Devonian and Middle Carboniferous (late Visean) are known in the FMC ([Lafon, 1986], [Duthou et al., 1994], [Cocherie et al., 2005], [Be Mezeme et al., 2005a], [Be Mezeme et al., 2005b] and [Faure et al., 2008]). The Middle Devonian event is related to the nappe stacking event ([Ledru et al., 1989] and [Faure et al., 2005] and enclosed references).

The pre-orogenic history of the North Gondwana margin is characterized by Andean-type continental margin controlled by the southward subduction of the Iapetus or Proto-Thethys ocean (570-520 Ma), followed by back-arc rifting episode (520-500 Ma) until the subsequent opening during the Early Ordovician (ca 490-485 Ma) of several oceanic domains separating micro-continents such as Armorica and Avalonia ([Matte, 2001], [Neubauer, 2002], [Stampfli et al., 2002], [Von Raumer et al., 2002] and [Von Raumer and Stampfli, 2008]).

Cambro-Ordovician orthogneiss linked to magmatic events related to this rifting episode are widely developed in the FMC (Table 1). Occurrences of Neoproterozoic ages are also noticeable in several plutons. Based on similar ages obtained in a sample of the UGU from the Limousin area and the previously known LGU ages, Alexandrov et al. (2000) argued for a similar pre-Variscan geotectonic domain. Alexandre (2007) emphasized three important magmatic events at $457 \pm 23 \mathrm{Ma}, 526 \pm 14 \mathrm{Ma}$, both related to pluton emplacement and 
$617 \pm 17 \mathrm{Ma}$ interpreted as the age of the protolith formed during the Cadomian orogeny. Moreover, lower crustal metasedimentary ganulitic ("kinzigite") enclaves hosted by the Miocene phonolite from Bournac (Leyreloup et al., 1977) in the eastern part of the FMC yielded inherited zircon ages from 630 to $430 \mathrm{Ma}$ with a peak between 550 and $430 \mathrm{Ma}$ (Fig. 1, point 7; Rossi et al., 2006). Few studies revealed the presence of Paleoproterozoic and Archean inherited ages (Table 1). In sedimentary series of the Montagne Noire area, in the South of the FMC, a wide range of ages has been found by (Gebauer et al., 1989), namely 2.9 Ga, 2.76 Ga, 2.6 Ga, 2.3 Ga, 2 Ga, $1 \mathrm{Ga}$ and $600 \mathrm{Ma}$. The presence of Paleoproterozoic and Neoproterozoic inherited zircons is also recognized in the LGU from the Limousin area (Alexandre, 2007).

\section{Sampling and analytical method}

Samples of paragneiss and orthogneiss were selected in the four tectonic units exposed in Limousin. Locations are reported in Fig. 2 and listed in Table 2.

After a densimetric separation of heavy minerals, hand-picked zircon grains were mounted in epoxy block and polished to obtain a uniform surface. Cathodoluminescence (CL) imaging was performed at University of Sciences and Technologies of Lille (UMR 8110 PBDS) and at University Pierre and Marie Curie (Paris 6) with a scanning electron microscope. Analyses on single grains were made using the Neptune MC-ICP-MS (ThermoElectron, Bremen, Germany) at BRGM (Orléans, France) equipped with a multi-ion counting system, allowing a very high sensitivity (Cocherie and Robert, 2007), and a laser ablation system (New Wave frequency-quintupled Nd:YAG UV laser, distributed by VG, UK) operating at $213 \mathrm{~nm}$. The ablation pit was $20 \mu \mathrm{m}$ in diameter and 15-20 $\mu \mathrm{m}$ deep. Argon gas was used as carrier gas. Zircon standard used is 91500 (Wiedenbeck et al., 1995). Standard bracketing was applied in order to correct both elemental fractionation during the ablation process and mass bias originating from the MC-ICP-MS itself. Detailed instrumentation and analytical accuracy descriptions are given in Cocherie and Robert (2008) and Cocherie et al. (2009).

Inverse and normal Concordia diagrams were generated using the Isoplot/Ex(3.1) program (Ludwig, 2004, Fig. 3, Fig. 4, Fig. 5 and Fig. 6). The selection or rejection of in situ ages determined on inherited zircons is a key point. The conventional Concordia diagram is used for old ages $(>1000 \mathrm{Ma})$. The ${ }^{207} \mathrm{~Pb} \cdot{ }_{*}^{*}{ }^{206} \mathrm{~Pb} *$ (radiogenic isotopes ratio) ages are taken into consideration only when the degree of discordancy is lower than $10 \%$. However, when a 
recrystallization age can be defined using a given grain (e.g. rim of a grain), the older inner age, if any (e.g. core of a grain) is considered to be the result of mixing process. In this situation, an upper intercept age is calculated and considered valid, even when discordancy of the analysis is higher than $10 \%$. For analyses younger than $1000 \mathrm{Ma}$, data are plotted in the Terra-Wasserburg Inverse Concordia diagrams (uncorrected for common $\mathrm{Pb}$ ). A minimum of one perfectly concordant analysis is required as well as minimum of 2-3 analyses to define the mixing line between the common $\mathrm{Pb}$ composition and the intercept with the Concordia curve.

Two methods were used to build the histogram representation (Fig. 7 and Fig. 8). For ages younger than $1000 \mathrm{Ma}$, the plotted data correspond to ${ }^{206} \mathrm{~Pb}{ }^{2}{ }^{238} \mathrm{U}$ ages of the analyses involved in the calculation of obtained ages in the Terra-Wasserburg Inverse Concordia diagram (see Tables 3, 4, 5 and 6 and Fig. 3 , Fig. 4, Fig. 5 and Fig. 6). For ages older than $1000 \mathrm{Ma}$, the plotted data correspond to the ${ }^{207} \mathrm{~Pb} * /{ }^{206} \mathrm{~Pb} *$ ages for concordant analysis or extrapolated ages in case of Discordia mixing line.

\section{Geochronological results}

Isotopic data are presented in Tables 3-6 (e-components) and plotted in Fig. 3, Fig. 4, Fig. 5 and Fig. 6. Ages and errors calculations were performed at $2 \sigma$ (95\% confidence level). Errors ellipses were plotted at $2 \sigma$ in the diagrams. Following the number of data $(n)$, the MSWD has to be lower than a theoretical value to ascertain the statistic validity of the calculated age (Wendt and Carl, 1991). For example, for 4 data, the MSWD should be under 2.6 whereas it should be under 1.6 for 20 data.

\subsection{Para-Autochthonous Unit}

\subsubsection{Millevaches micaschist (South Argentat) (Li10) (Tables 3 and 4; Fiq. 3 A and}

\section{B)}

Ten spots were analysed on 10 zircon grains. Four analyses yield a lower intercept age of $604 \pm 16 \mathrm{Ma}$ in the inverse concordia diagram, anchoring the data with a common $\mathrm{Pb}$ point (Fig. 3), with an acceptable MSWD value (2.9). Two analyses clearly show radiogenic $\mathrm{Pb}$ loss. Four analyses give older clastic zircon ages. Two concordant ages were obtained, at 
$2102 \pm 106 \mathrm{Ma}$ for the grain 7 whereas grain 1 yield a slightly discordant age at $1764 \pm 120 \mathrm{Ma}$.

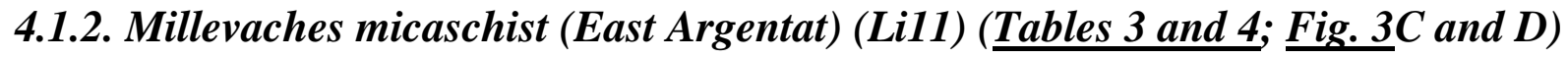

Twenty four analyses were performed on 18 zircon grains for this sample. Ten of them show radiogenic $\mathrm{Pb}$ loss. Six analyses, with 3 of them concordant, yield an age of $631 \pm 18 \mathrm{Ma}$ with an acceptable MSWD value (2.5). Remarkably, the two micaschists of the Para-

Autochthonous Unit show almost exactly the same Pan-African younger age in the detrital zircons population, corresponding to the maximum deposition age. Three younger concordant analyses were obtained but the cathodoluminescence pictures showing domains very similar to the population dated at $631 \pm 18 \mathrm{Ma}$, we considered that these analyses show radiogenic $\mathrm{Pb}$ loss. Several older clastic zircon ages were obtained. Grain 14 gave a concordant age $964 \pm 22 \mathrm{Ma}\left({ }^{207} \mathrm{~Pb} /{ }^{206} \mathrm{~Pb}\right.$ age $)$. Even if grains 4, 5 and 15 are strongly discordant, they allow drawing a Discordia line with an upper intercept at 2866 \pm 50 Ma. Grain 9, clearly discordant, yield an age at $2036 \pm 79 \mathrm{Ma}$, kept for its similarity to a concordant age from Li10 sample.

\subsubsection{Moulin du Chambon orthogneiss (Li14) (Tables 3 and 4; Fig. 3E)}

Thirty five analyses were done on 27 zircon grains. The majority of the population (17 grains) yields an age of $529 \pm 4 \mathrm{Ma}$ with 11 spots concordant and a MSWD value of 1.6. This age is considered as the magmatic emplacement age of the granite. The other grains show radiogenic $\mathrm{Pb}$ loss, and for two of them, two discordant older inherited ages that were not considered for the age calculation.

\subsection{Lower Gneiss Unit (LGU)}

\subsubsection{Tulle orthogneiss (Li05) (Tables 3 and 4; Fiq. 4A and B)}

Twenty six analyses were performed on 19 zircon grains. Zircons from this sample yield two groups of ages: five analyses gave, with an acceptable MSWD value (2.8), an intercept age at $470 \pm 11 \mathrm{Ma}$, interpreted as the magmatic emplacement age and three an intercept age at $641 \pm 11 \mathrm{Ma}$. Two other spots yield an age at $540 \pm 10 \mathrm{Ma}$ and $1801 \pm 89 \mathrm{Ma}$ (grains 8 and 10). A third one gave a minimum age at $2111 \pm 48 \mathrm{Ma}$ and a maximum at $2266 \pm 61 \mathrm{Ma}$ (grain 7). 


\subsubsection{Cornil paragneiss (Li06) (Tables 4 and 5; Fig. 4C and D)}

Twenty eight analyses were performed on 25 zircon grains. Two detrital populations yield intercept ages at $670 \pm 22$ and $573 \pm 12 \mathrm{Ma}$ (4 spots for each). The youngest constrains deposition of the sediment protolith to be younger than $573 \pm 12 \mathrm{Ma}$. Grain 17 gave a concordant age at $1060 \pm 18 \mathrm{Ma}$. Grains 5 and 10 gave two discordant ages at $2071 \pm 94 \mathrm{Ma}$ and $2775 \pm 34 \mathrm{Ma}$. The others spots show radiogenic $\mathrm{Pb}$ loss.

\subsubsection{Aubazine micaschist (Li07) (Tables 4 and 5; Fig. 4E and F)}

Fifteen zircons grains were analysed for this sample, with a total of twenty spots. Seven of them show radiogenic $\mathrm{Pb}$ loss. The youngest detrital population, as defined by 8 analyses, confines the maximum deposition age at $593 \pm 4 \mathrm{Ma}$. Concordant age at $879 \pm 32 \mathrm{Ma}$ was obtained for grain 14. Grain 15 gave a slightly discordant age at $1715 \pm 99$ Ma. A discordant analyze (grain 2) resulted on an extrapolated age at $2662 \pm 36 \mathrm{Ma}$.

\subsubsection{Aubazine orthogneiss (Li08) (Table 5; Fiq. 4G)}

Eight analyses on 8 zircon grains were done for this sample. Five concordant analyses yields an age at $475 \pm 11 \mathrm{Ma}$ with a valuable MSWD at 0.9 , considered as the age of the magmatic emplacement of the granitic pluton.

\subsubsection{Meuzac orthogneiss (Li23) (Table 5; Fig. 4H)}

In this sample, 38 analyses were performed on 27 zircon grains. Two populations could be distinguished: one yield an age of $451 \pm 5 \mathrm{Ma}$ (MSWD $=1.4$ for 14 analyses) representing the age of the magmatism. The second population shows variable radiogenic $\mathrm{Pb}$ loss, and consequently was not used for age calculation.

\subsubsection{Port de Vaurs orthogneiss (Li09) (Tables 4 and 5; Fig. 5A and B)}

Twenty six analyses were performed on 18 zircon grains. The youngest $\mathrm{U}-\mathrm{Pb}$ measurements giving an age of $464 \pm 9 \mathrm{Ma}$, with valuable MSWD at 2.2, is considered to represent the age of the magmatic emplacement of the granitic pluton. Several inherited ages were obtained. Two concordant analyses results in an age of $733 \pm 18 \mathrm{Ma}$. Grain 18 shows a concordant age at $1932 \pm 48 \mathrm{Ma}$. Grains 11 and 14 gave discordant ages at $1836 \pm 46 \mathrm{Ma}$ and $2717 \pm 48 \mathrm{Ma}$. 
Three analyses spread along a discordant line with an upper intercept at $2116 \pm 50 \mathrm{Ma}$. These five analyses are highly discordant, however as far as the related domains are associated with rims dated at $464 \mathrm{Ma}$, it is possible to extrapolate the mixing line until the Concordia from this young age (Fig. 5B).

\subsection{Upper Gneiss Unit (UGU)}

\subsubsection{Ceaulmont orthogneiss (Li01) (Table 6; Fig. 6A)}

Thirty analyses were performed on 23 zircon grains. Most of the analyses show significant radiogenic $\mathrm{Pb}$ loss and common $\mathrm{Pb}$ contribution. Mainly, three concordant ages were obtained: (i) $349 \pm 14 \mathrm{Ma}$, which can be considered as record of a Variscan metamorphic event (ii) $574 \pm 28 \mathrm{Ma}$ corresponding to the magmatic protolith emplacement (iii) and $763 \pm 28 \mathrm{Ma}$ as inherited ages.

\subsubsection{Seilhac paragneiss (Li03A) ( $\underline{\text { Table } 6 \text {; Fig. } 6 \text { B }) ~}$}

In this sample, twenty five zircons grains were analyzed for a total of 26 spots. $\mathrm{U}-\mathrm{Pb}$ data from the Seilhac paragneiss gave two main zircon populations. The first one gave an age at $523 \pm 4 \mathrm{Ma}$, with a valuable MSWD at 1.1 for 4 analyses, and the second at $555 \pm 7 \mathrm{Ma}$ with MSWD at 2.3 for 7 analyses. The younger age represents the maximum sedimentation age of this formation. Two concordant analyses (grains 15 and 5) results in an age at $710 \pm 90 \mathrm{Ma}$.

\subsubsection{Plateau d'Aigurande migmatitic paragneiss (Li25) (Tables 4 and 6; Fiq. 6 C and $D)$}

Forty six analyses were performed on 35 zircon grains. Six analyses yield an age of $558 \pm 9 \mathrm{Ma}$. This younger age can be considered as the maximum deposition age of this formation. Grain 19 gave a concordant age at $713 \pm 52$ Ma. Several older clastic zircons, concordant or slightly discordant, or spread on Discordia lines gave the following ages: $1722 \pm 44 \mathrm{Ma}$ (grains 7, 2, 3, 16; no rims were associated to these cores, then a better fit was found using a mixing line passing through the origin), $2452 \pm 20 \mathrm{Ma}$ (grains 12 and 17), $2666 \pm 13$ (grains 4, 11 and 17), $2841 \pm 9 \mathrm{Ma}$ (grains 6 and 2) and $3126 \pm 25 \mathrm{Ma}$ (grain 22). 


\subsection{Thiviers-Payzac Unit}

\subsubsection{Saut du Saumon orthogneiss (Li16) ( $\underline{\text { Table 6 }}$; Fiq. 6E)}

Twenty two analyses were performed on sixteen zircon grains. Two populations yield two different ages at $501 \pm 5 \mathrm{Ma}$ (MSWD $=0.81$ for 10 analyses) and $776 \pm 14 \mathrm{Ma}$ (MSWD $=0.4$ for 3 analyses). The emplacement of the protolith of this orthogneiss can be considered as Cambrian.

\subsubsection{Clair Vivre metarhyolite (Li19) ( $\underline{\text { Table 6; Fig. 6F) }}$}

Eighteen analyses were performed on 18 grains. A population of 7 analyses yields an age at $475 \pm 6 \mathrm{Ma}$ (with a valuable MSWD value at 1.9 for 7 analyses), which can be considered as the age of the magmatic event.

\subsubsection{Metasandstone (Li22 (Tables 4 and 6; Fiq. 6 G and H))}

Twenty six analyses were performed on 24 zircon grains. A first population of 9 analyses yields an age of $564 \pm 9 \mathrm{Ma}$. Grain 1 is concordant at $871 \pm 14 \mathrm{Ma}$. Combining this analysis with that of grains 9 and 18, an average age of $894 \pm 18$ Ma can be calculated. Four analyses spread along a Discordia line giving an upper intercept at $2035 \pm 28$ Ma. One zircon grain (9) gave a discordant age at $3284 \pm 64 \mathrm{Ma}$, whose Discordia lower intercept is constrained by the obtained age at the rim linked to the population at $894 \pm 18 \mathrm{Ma}$.

\section{Discussion}

This contribution provides fifty in situ U-Pb ages on zircon summarized in Fig. 7. In the following, we discuss the implications of these results on the chronology of the Late Neoproterozoic and Early Paleozoic magmatic events, on the deposition age of the sedimentary formations and on the provenance of the zircon inheritance.

\subsection{Late Neoproterozoic and Early Paleozoic magmatism}

In this study, several Lower Paleozoic zircon age populations were obtained, showing peaks around $531 \mathrm{Ma}$ and $473 \mathrm{Ma}$ (Fig. 8) in the magmatic samples. No differences were observed between the various tectonostratigraphic units. Indeed, the Moulin du Chambon (Para- 
Autochthonous unit) and the Saut du Saumon orthogneiss (Thiviers-Payzac Unit) yield emplacement ages at $529 \pm 4 \mathrm{Ma}$ and $501 \pm 5 \mathrm{Ma}$ whereas several other orthogneiss lead to Ordovician ages: $470 \pm 11 \mathrm{Ma}$ for the Tulle orthogneiss, with an inherited age at $540 \pm 10 \mathrm{Ma}, 475 \pm 11 \mathrm{Ma}$ for the Aubazine orthogneiss, $451 \pm 5 \mathrm{Ma}$ for the Meuzac orthogneiss (LGU), $464 \pm 9$ Ma for the Port-de-Vaurs orthogneiss in the LGU, and $475 \pm 6$ for the Clair Vivre metarhyolite (Thiviers-Payzac Unit). Cambrian ages are known in the FMC and other parts of the Variscan belt. $\underline{\text { Lafon (1986) }}$ dated the Caplongue granodiorite at $557+12-10 \mathrm{Ma}$, where as Alexandrov (2000) obtained an age at $525 \pm 6 \mathrm{Ma}(\mathrm{U}-\mathrm{Pb}$ on zircon) for the Vergonzac orthogneiss. Ducrot et al. (1979) found an age at $532 \pm 13$ for the Plaisance orthogneiss (Fig. 1-14). Ordovician orthogneiss are also largely widespread in the Variscan belt. In the FMC, the Mont du Lyonnais orthogneiss yields ages at $467 \pm 10 \mathrm{Ma}$ and

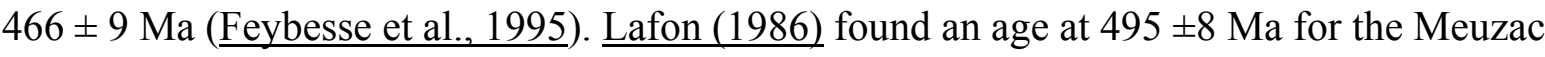
orthogneiss. Several orthogneiss yield Cambrian and Ordovician ages in the Montagne Noire and the Pyrenees ([Roger et al., 2004] and [Cocherie et al., 2005]) and in Southern Brittany (Jegouzo et al., 1986).

Detrital zircons from the sedimentary samples investigated lead to peaks around $592 \mathrm{Ma}$ and $557 \mathrm{Ma}$ (Fig. 9). It is worth noting that in the detrital zircon record presented in the sedimentary samples, there are almost continuous remnants between $680 \mathrm{Ma}$ and $550 \mathrm{Ma}$, whereas in the magmatic samples, they are just few occurrence between $620 \mathrm{Ma}$ and $540 \mathrm{Ma}$ (Fig. 8 and Fig. 9).

In the pre-Variscan formations of the Eastern Pyrenees, Castiñeiras et al. (2008) highlighted the existence of two major events at 580-540 Ma and 475-460 Ma. The first one is well represented in the sedimentary formations investigated during this work, with a peak at $560 \mathrm{Ma}$ (Fig. 9). In the magmatic formations, the peak of activity is slightly younger at $531 \mathrm{Ma}$ (Fig. 8). In the FMC, the second event seems to take place from $490 \mathrm{Ma}$ to $450 \mathrm{Ma}$, then during almost $40 \mathrm{Ma}$.

These results are in good agreement with proposed models on the evolution of the North Gondwana margin. According to Matte (2001), Stampfli et al. (2002) and Von Raumer et al. (2003), at the end of the Neoproterozoic (570-520 Ma), the North Gondwana margin is characterized by an active margin with continental arc-related magmatism and volcanodetrital formations in a back-arc basin (Fernández et al., 2008). At the end of Cambrian and the beginning of Ordovician (490-470), the back-arc basin developed to induce the formation 
of a true ocean in its western part, leading to the drift of Avalonia from Gondwana. The Ordovician magmatic activity, largely widespread at the North Gondwana margin ([Pin and Marini, 1993] and [Von Raumer et al., 2003]), and unrelated to any regional metamorphic event, might represent evidence of rifting process leading to the separation of the South European microcontinents such as Armorica from Gondwana. Our geochronological data provide new information about the duration of the rifting event taking place along the North Gondwana margin during Cambro-Ordovician times. Indeed, the last dated magmatic emplacement at around 450 Ma shows that this event was still active on until the end of the Ordovician in this area, which is in good agreement with obtained results of Friedl et al. (2004) in the Bohemian massif. The general Cambro-Ordovician continental breakup of North Gondwana might also be link to mantle plume ([Crowley et al., 2000] and [Floyd et al., 2000]). Cocherie et al. (2005) highlighted the abnormal high thermal environment linked to melting stages of the pre-Variscan magmatic plutons in the Pyrenees and the Montagne Noire. This high thermal setting could be a possible explanation for the lack of preservation of old relics in the youngest Ordovician granitoids (see below).

\subsection{Deposition age of the sedimentary sequences}

Obtained ages on detrital zircon from Precambrian and Lower Paleozoic metasedimentary rocks of the French Massif Central bring new constraints on the maximum depositional ages of these formations. In the Para-Autochthonous Unit, the youngest obtained ages on the Millevaches micaschist are $604 \pm 16 \mathrm{Ma}$ and $631 \pm 18 \mathrm{Ma}$ in Li10 and Li11 samples respectively; thus the maximum depositional age for this formation is Ediacarian. Detrital zircon from the Cornil paragneiss and the Aubazine micaschist, both from the LGU, yield respectively Precambrian ages at $573 \pm 12$ and $593 \pm 4$ Ma. In the UGU, youngest obtained ages in the Plateau d'Aigurande migmatitic paragneiss and Seilhac paragneiss are $558 \pm 9 \mathrm{Ma}$ and $523 \pm 4$ Ma respectively. Detrital zircons hosted in metasandstone from the ThiviersPayzac Unit yield Early Cambrian age at $564 \pm 9$ Ma. Literature data for deposition ages of these sedimentary sequences are unfortunately lacking. Nevertheless, all these formations are crosscut by pre-orogenic Cambrian and Ordovician plutons (Fig. 7). Then, obtained results in the magmatic formations provide minimum depositional ages, in good coherence with the maximum ages given by detrital zircons for the Para-Autochthonous Unit, the LGU and the Thiviers-Payzac Unit (Fig. 7). In the UGU, the obtained age in the Ceaulmont orthogneiss at $574 \pm 28 \mathrm{Ma}$, could be interpreted as the emplacement age but it is older than the youngest 
detrital zircons from the studied sedimentary formations. The age at $349 \pm 14 \mathrm{Ma}$ is coeval with the regional metamorphism and then cannot correspond to the magmatic event. However, the low number of analysis leading to the age at $574 \pm 28 \mathrm{Ma}$ (Fig. 6A) and the important amount of younger analysis showing radiogenic $\mathrm{Pb}$ loss and mixing with the common $\mathrm{Pb}$ values can imply that this age correspond to inheritance, and the emplacement age would be located between 500 and $400 \mathrm{Ma}$.

Even if the number of studied samples is low, in the present geometric stack of nappes, it seems that a significant difference exists in the maximum depositional ages of the ParaAutochthonous Unit, the LGU and the UGU formations. Moreover, the LGU and the Thiviers Payzac Unit show close maximum depositional ages. Further works are necessary to discuss in detail the paleogeographic implications of these results.

\subsection{Age inheritance}

The correlation of the detrital and inherited zircon populations (Fig. 7, Fig. 8 and Fig. 9) with published ages from nearby areas allows us to discuss possible source areas. Inherited and clastic zircons ages obtained in the analyzed samples lead to a huge amount of Archean and Proterozoic ages and it is possible to distinguish a several groups of age: $3.2 \mathrm{Ga}, 2.9-2.4 \mathrm{Ga}$, 2.3-2.0 Ga, and 1.9-1.6 Ga (Fig. 7). Similar ages are widely known in western Europe for example in Montagne Noire and Limousin ([Gebauer et al., 1989] and [Alexandre, 2007]), and other massifs of the North Gondwana margin, such as in Neoproterozoic and Lower Paleozoic metasedimentary and volcanosedimentary rocks of NW Spain ([Fernández-Suárez et al., 2000], [Montero et al., 2007] and [Castiñeiras et al., 2008]), in Calabrian orthogneiss (Micheletti et al., 2007), in orthogneiss from the Ruitor massif in internal Western Alps (Guillot et al., 2002) or in metasediments and orthogneiss of the Cyclades in Greece (Keay and Lister, 2002). Moreover, Armorican metasediments of the Mid-German Crystalline Rise in Central Germany (Gerdes and Zeh, 2006) also show such zircon populations. As remarked by Gebauer et al. (1989) and Keay and Lister (2002), Mesoproterozoic ages, related to the Avalonian terranes and the Grenville belts ([Mallard and Rogers, 1997] and [Murphy et al., 2006]) are remarkably lacking, characterizing the Gondwanan affinity of the inherited zircons. Similar ages are well known in outcroping formations in the West African craton. In Mauritania, the Reguibat Rise is the result of a Mesoarchean event (around 3.1 Ga), reworked by Birimian event (2.3 to 2.0 Ga) (Lahondére et al., 2004). Orosirian ages (1.9-1.7 Ga) are 
also known in Moroccan Anti-Atlas, corresponding to the Eburnean basement (Gasquet et al., 2005). However, the Grenvillian signature (1.1-0.9 Ga) recorded by detrital zircons in Neoproterozoic and Lower Paleozoic sedimentary formations of the Variscan belt could support the evidence of a feeding from the South American crust in Central Europe and NW Iberia ([Friedl et al., 2000], [Fernández-Suárez et al., 2000] and [Guttiérrez-Alonso et al., 2003]). But recent study documented also Grenvillian granitoids in the Taoudeni basin in North Gondwana, far of the Amazonian source (D. Lahondère, pers. com.), arguing possibly for a North African source as well. Indeed, a possible crustal thinning dated around 1.1$1.0 \mathrm{Ga}$ is recorded in the Adrar Souttouf massif, in the Moroccan Mauritanides (Villeuneuve et al., 2006).

Pan-African inherited and clastic zircons ages found in the French Massif Central compose a large population in the detrital zircons analyzed in this present work. Thus, in agreement with Gebauer et al. (1989), the distribution of zircon inheritance in metasedimentary formations of the FMC reveals a West African provenance. Archean and Paleoproterozoic inherited and clastic zircons ages highlight the contribution of an old continental crust submitted to erosion. However, this contribution seems not very important in comparison to the important Neoproterozoic and Cambrian zircons occurrence, which represents at least $60 \%$ of the total analyzed zircons. In this population, two age peaks can be distinguished at $592 \mathrm{Ma}$ and $557 \mathrm{Ma}(\underline{\text { Fig. 9 }})$.

The two Tonian ages (at $879 \pm 32 \mathrm{Ma}$ and $894 \pm 18 \mathrm{Ma}$, Fig. 9) in the French Massif Central are unknown in the West African craton, but such ages were described in the Brazilian shield and could correspond to remnants of plutono-volcanic intra-oceanic arcs related to subduction and predating a first collisionnal event (Brasiliano I) (Medeiros Delgado et al., 2003). Thus, such detrital zircons could have originated by the erosion of magmatic rocks related to this activity, and presently not outcroping in the West African craton.

Ediacarian and Cryogenian ages correspond to the remnants of magmatic formations emplaced during the Pan-African events. Gasquet et al. (2005) described two main stages of magmatic activity in the Anti-Atlas domain in Morocco: (i) ocean opening followed by subduction-related arc magmatism (790-690 Ma), with activity peaks at $790 \mathrm{Ma}$ and $690 \mathrm{Ma}$ (ii) ocean closure followed by arc-continent collision (690-605 Ma), with peaks at 660 and $615 \mathrm{Ma}$. 
These results show some differences with obtained ages in granulitic metasedimentary xenoliths in the Bournac volcano, which represent samples of the Variscan lower crust, with age peaks at $630 \mathrm{Ma}, 520 \mathrm{Ma}$ and $440 \mathrm{Ma}$ (Rossi et al., 2006). The deposition of these sediments took place after $440 \mathrm{Ma}$, then after the sedimentation of the formation studied in this work. Moreover, a possible source of the Bournac inherited zircons could be the Paleozoic accretionary prism subducted during the Variscan collision.

\subsection{Inheritance in the pre-Variscan magmatic rocks of the French Massif Central}

The investigated Cambro-Ordovician orthogneiss displays a large abundance of inherited zircons, whereas some, in particular most of the youngest orthogneiss, do not contain any inherited zircons. Several explanations can be suggested to account for the existence of these differences. First, it could be simply due to the heterogeneity between the different source materials composing the protolith of these orthogneiss. A second explanation could be related to the melting and emplacement processes. In zirconium undersatured melts, zircon would be dissolved. Due to the dependence of zircon dissolution in anatectic melts with the melt composition, the water content and the temperature, only large crystals $(>50-100 \mu \mathrm{m})$ survive crustal melting and incorporation into a $2 \mathrm{wt} . \% \mathrm{H}_{2} \mathrm{O}, 750-850{ }^{\circ} \mathrm{C}$, zircon undersaturated melt (Watson, 1996). The presence of halogens can also have an influence on the zircon dissolution (Baker et al., 2002). Montero et al. (2007) argued that fast processes of melting, melt segregation and emplacement, that would not give enough time for zircon dissolution or re-opening of the $\mathrm{U}-\mathrm{Pb}$ system, could be at the origin of the high inheritance of orthogneiss in the Ollo de Sapo Domain (Central Spain). This implies an important heterogeneity of magmatic processes leading to the emplacement of these plutons. A third possibility might be that this magmatism corresponds to juvenile arc-related magmatism, without any contamination during the ascent of magma. However, this last hypothesis remains unlikely.

The inherited zircon occurrences found in the Cambro-Ordovician orthogneiss investigated during this study are similar to the populations from the metasedimentary rocks (Fig. 8 and Fig. 9), with Archean, Paleoproterozoic and a dominant presence of Neoproterozoic inheritances. Thus, these results support the West African craton as the source area of these magmatic rocks. 


\subsection{West European continental crust formation}

This study does not support direct evidence for a pre-Variscan basement under the Neoproterozoic-Early Paleozoic sedimentary formations of FMC. Both ortho and paraderived samples yield the same range of inherited or clastic zircons ages and no important difference was revealed between the two types of rocks. But the North Gondwana affinity demonstrated before and the inherited ages obtained in orthogneiss allow us to assume that such a basement was intensively reworked during Pan-African or Orosirian events. A large amount of formations linked to these events crops out in North Africa (Gasquet et al., 2005).

The important amount and the variety of inherited and clastic zircon ages obtained in this study allow us to speculate about the timing of continental crust accretion. Juvenile continental crust is produced from mantle melting at two tectonic settings: (i) subduction zones ([Dewey and Horsfield, 1970] and [Ringwood, 1974]) and (ii) intraplate mantle plumes ([Malloe, 1982], [Kröner and Layer, 1992] and [Stein and Hofmann, 1994]). Previous studies argued for two different models, namely continuous or during growth peaks, the major amount during Archean and Paleoproterozoic times. In regard of the inherited and clastic zircons ages obtained in this study, episodic growth hypotheses seem better constrained. Our results are in good agreement with major events at 2.7-2.6 Ga and 1.9-1.8 Ga (Condie, 1998).

Our results together with previous studies highlight the importance of Neoproterozoic and Lower Paleozoic events in Western Europe, characterized by a large amount of granitic plutonism. In the light of the evolution of the Northern Gondwana margin, with an important history as active margin with continental arc-related subduction, an important episode of juvenile continental crust formation could take place at the end of the Neoproterozoic and the beginning of the Paleozoic in Western Europe. Gerdes and Zeh (2006) argued in favour of this hypothesis in Central Germany. Our results also closely agree with the growth history of continental crust as recently proposed by Rino et al. (2008) who proposed that the Neoproterozoic and Pan-African were significant periods in Earth history for juvenile crustal growth based on a large amount of zircon data from major river mouths of the world.

\section{Conclusion}


LA-MC-ICP-MS in situ U-Pb systematic dating of zircon grains from ortho and paragneisses from the four main tectonostratigraphic units of the Limousin area (French Massif Central) provide a wide range of inherited and clastic zircon ages from Archean to Early Paleozoic.

Magmatic emplacement ages obtained for the orthogneiss range between $521 \pm 7$ and $446 \pm 6 \mathrm{Ma}$. Considering all the results from both magmatic and metasedimentary samples, two peaks at 531 and $473 \mathrm{Ma}$ are recognized. The ca $450 \mathrm{Ma}$ last dated magmatic events suggest that the rifting episode lasted a long period, at least since $490 \mathrm{Ma}$ to $450 \mathrm{Ma}$, i.e. the entire Ordovician.

Several maximum depositional ages were obtained in the metasedimentary formations of the FMC, ranging from $604 \pm 16$ Ma for metasediments of the Para-Autochthonous unit, $573 \pm 12 \mathrm{Ma}$ for the LGU, $564 \pm 9$ Ma for the Thiviers Payzac unit, and $523 \pm 4 \mathrm{Ma}$ in the UGU, with a decrease of this maximum age upwards in the tectonostratigraphy.

The population of detrital zircon in metasedimentary formations yielded a wide spectrum of ages with significant peaks at around $590 \mathrm{Ma}$ and $560 \mathrm{Ma}$. The Archean, Paleoproterozoic and Neoproterozoic detrital zircons suggest a West African craton affinity of the sedimentation. With a large representation in the inherited and detrital zircon populations, Neoproterozoic and Lower Paleozoic events played an important role in the continental crustal growth of Western Europe.

\section{Acknowledgements}

The authors wish to thank M. Robert for the excellent analyses processing. We are also indebted to O. Boudouma (Laboratoire Magie, UPMC) and P. Recourt (Laboratoire Géosystème, UMR 8157, University of Lille 1) for the cathodoluminescence imaging. Detailed reviews and constructive comments by F. Finger and an anonymous reviewer helped us to improve an initial version of the manuscript. This contribution was supported by the "Région Centre" and by BRGM (French Geological Survey).

\section{References}

Alexandre, $2007 \mathrm{P}$. Alexandre, U-Pb SIMS ages from the French Massif Central and implication for the pre-Variscan tectonic evolution in Western Europe, Comptes Rendus Geosciences 339 (2007), pp. 613-621. 
Alexandrov, 2000 Alexandrov, P., 2000. Géochronologie U/Pb et ${ }^{40} \mathrm{Ar} /{ }^{39} \mathrm{Ar}$ de deux segments de la chaîne varisque: le haut Limousin et les Pyrénées orientales. Ph.D. Thesis, 186 p., Institut National Polytechnique de Lorraine, Univ. Nancy.

Alexandrov et al., 2000 P. Alexandrov, J.-P. Floc'h, M. Cuney and A. Cheilletz, Datation U$\mathrm{Pb}$ à la microsonde ionique des zircons de l'unité supérieure de gneiss dans le Sud Limousin, Massif Central. Comptes Rendus de l'Académie des Sciences, Paris 332 (2000), pp. 625-632. Baker et al., 2002 D.R. Baker, A.M. Conte, C. Freda and L. Ottolini, The effect of halogens on $\mathrm{Zr}$ diffusion and zircon dissolution in hydrous metaluminous granitic melts, Contribution to Mineralogy and Petrolology 142 (2002), pp. 666-678.

Be Mezeme et al., 2005a E. Be Mezeme, A. Cocherie, M. Faure, O. Legendre and P. Rossi, Electron microprobe monazite dating of magmatic events: examples from Variscan migmatites and granitoids, Massif Central, France, Lithos 87 (2005), pp. 276-288. Be Mezeme et al., 2005b E. Be Mezeme, M. Faure, A. Cocherie and Y. Chen, In situ chemical dating of tectonothermal events in the French Variscan Belt, Terra Nova 17 (2005), pp. $420-426$.

Calvez and Vidal, 1978 J.-Y. Calvez and P. Vidal, Two billion years old relicts in the hercynian belt of Western Europe, Contribution to Mineralogy and Petrolology 65 (1978), pp. 395-399.

Caron, 1994 Caron, C., 1994. Les minéralisations Pb-Zn associées au Paléozoique inférieur d'Europe méridionale. Ph.D. Thesis, 226 p., Université Montpellier II.

Castiñeiras et al., 2008 P. Castiñeiras, M. Navidad, M. Liesa, J. Carreras and J.M. Casas, U$\mathrm{Pb}$ zircon ages (SHRIMP) for Cadomian and Early Ordovician magmatism in the Eastern Pyrenees: new insights into the pre-Variscan evolution of the northern Gondwana margin, Tectonophysics 461 (2008), pp. 228-239 10.1016/j.tecto.2008.04.005.

Cocherie and Robert, 2007 A. Cocherie and M. Robert, Direct measurement of lead isotope ratios in low concentration environmental samples by MC-ICP-MS and multi-ion counting, Chemical Geology 243 (2007), pp. 90-104.

Cocherie and Robert, 2008 A. Cocherie and M. Robert, Laser ablation coupled with ICP-MS applied to $\mathrm{U}-\mathrm{Pb}$ zircon geochronology: a review of recent advances, Gondwana Research 14 (2008), pp. 597-608.

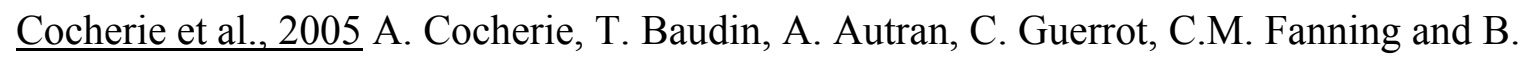
Laumonier, U-Pb zircon (ID-TIMS and SHRIMP) evidence for the early ordovician intrusion of metagranites in the late Proterozoic Canaveilles Group of Pyrenees and the Montagne Noire (France), Bulletin de la Société Géologique de France 176 (2005), pp. 269-282. 
Cocherie et al., 2009 A. Cocherie, C.M. Fanning, P. Jezequel and M. Robert, LA-MC-ICPMS and multi-ion counting system, and SHRIMP U-Pb dating of complex zircons from quaternary tephras from the French Massif Central: magma residence time and geochemical implications, Geochimica Cosmochimica Acta 73 (2009), pp. 1095-1108.

Condie, 1998 K.C. Condie, Episodic continental growth and supercontinents: a mantle avalanche connection?, Earth and Planetary Sciences Letters 163 (1998), pp. 97-108. Condie et al., 2009 K.C. Condie, E. Belousova, W.L. Griffin and K.N. Sircombe, Granitoid events in space and time: constraints from igneous and detrital zircon age spectra, Gondwana Research 15 (2009), pp. 228-242.

Crowley et al., 2000 Q.J. Crowley, P.A. Floyd, J.A. Winchester, W. Franke and J.G. Holland, Early Paleozoic rift related magmatism in Variscan Europe: fragmentation of the Armorican Terrane Assemblage, Terra Nova 12 (2000), pp. 171-180.

Dewey and Horsfield, 1970 J.F. Dewey and B. Horsfield, Plate tectonics, orogeny and continental growth, Nature 225 (1970), pp. 521-525.

Ducrot et al., 1979 J. Ducrot, J.R. Lancelot and J.L. Reille, Datation en Montagne Noire d'un témoin d'une phase majeure d'amincissement crustal caractéristique de l'Europe prévarisque, Bulletin de la Société Géologique de France 7 (1979), pp. 501-505.

Duthou et al., 1994 J.-L. Duthou, M. Chenevoy and M. Gay, Age Rb/Sr Dévonien moyen des migmatites à cordierite du Lyonnais (Massif Central français), Comptes Rendus Académie Sciences, Paris 319 (1994), pp. 791-796 II.

Faure et al., 2005 M. Faure, E. Bé Mézème, M. Duguet, C. Cartier and J.-Y. Talbot, Paleozoic tectonic evolution of medio-Europa from the example of the French Massif Central and Massif Armoricain, Journal of Virtual Explorer 19 (2005) paper 5.

Faure et al., 2008 M. Faure, E. Bé Mézème, A. Cocherie, P. Rossi, A. Chemenda and D. Boutelier, Devonian geodynamic evolution of the Variscan Belt, insights from the French Massif Central and Massif Armoricain, Tectonics 27 (2008), p. TC2005 $\underline{10.1029 / 2007 T C 002115 .}$.

Fernández-Suárez et al., 2000 J. Fernández-Suárez, G. Guttiérrez-Alonso, G.A. Jenner and M.N. Tubrett, New ideas on the Proterozoic-Early Paleozoic evolution of NW Iberia: insights from U-Pb detrital zircon ages, Precambrian Research 102 (2000), pp. 185-206.

Fernández et al., 2008 C. Fernández, R. Becchio, A. Castro, J.M. Viramonte, I. MorenoVentas and L.G. Corretge, Massive generation of atypical ferrosilicic magmas along the Gondwana active margin: implications for cold plumes and back-arc magma generation, Gondwana Research 14 (2008), pp. 451-473. 
Feybesse et al., 1995 Feybesse, J.L., Lardeaux, J.M., Tegyey, M., Gardien, V., Peterlongo, J.M., Kerrien, Y., Becq-Giraudon, J.F., 1995. Carte géologique de la France (1/50000), feuille Saint Symphorien (721). Orléans: BRGM. Notice explicative, $110 \mathrm{p}$.

Floc, 1983 Floc'h, J.P., 1983. La série métamorphique du Limousin central. PhD thesis, Limoges (France), $455 \mathrm{pp}$.

Floyd et al., 2000 P.A. Floyd, J. Winchester, R. Seston, R. Kryza and Q.G. Crowley, Review of the geochemical variation in the Lower Palaeozoic metabasites from the NE Bohemian Massif: intracratonic rifting and plume-ridge interaction. In: W. Franke, R. Altherr, V. Haak, O. Oncken and D. Tanner, Editors, Orogenic Processes - Quantification and Modeling of in the Variscan Belt of Central Europe, Geological Society of London, Special Publications vol. 179 (2000), pp. 103-112.

Friedl et al., 2000 G. Friedl, F. Finger, N.J. McNaughton and I.R. Fletcher, Deducing the ancestry of terranes: SHRIMP evidence from South America derived Gondwana fragments in central Europe, Geology 28 (2000), pp. 1035-1038.

Friedl et al., 2004 G. Friedl, F. Finger, J.-L. Paquette, A. von Quadt, N.J. McNaughton and I.R. Fletcher, Pre-Variscan geological events in the Austrian part of the Bohemian Massif deduced from U-Pb zircon ages, International Journal of Earth Sciences 93 (2004), pp. 802823.

Gasquet et al., 2005 D. Gasquet, G. Levresse, A. Cheilletz, M.R. Azizi-Samir and A. Mouttaqi, Contribution to a geodynamic reconstruction of the Anti-Atlas (Morocco) during Pan-African times with the emphasis on inversion tectonics and metallogenic activity at the Precambrian-Cambrian transition, Precambrian Research 140 (2005), pp. 157-182.

Gebauer et al., 1981 D. Gebauer, J. Bernard-Griffiths and M. Grünenfelder, U-Pb zircon and monazite dating of a mafic-ultramafic complex and its country rocks. Example: Sauviat-surVige, French Central Massif, Contribution to Mineralogy and Petrology 76 (1981), pp. $292-$ 300 .

Gebauer et al., 1989 D. Gebauer, I.S. Williams, W. Compston and M. Grünenfelder, The development of the central continental crust since the early archean based on conventional and ion microprobe dating up to 3.84 By old detrital zircons, Tectonophysics 157 (1989), pp. 81-96.

Gerdes and Zeh, 2006 A. Gerdes and A. Zeh, Combined U-Pb and Hf isotope LA-(MC)ICPMS analyses of detrital zircons: comparison with SHRIMP and new constraints for the provenance and age of an Armorican metasediment in Central Germany, Earth and Planetary Sciences Letters 249 (2006), pp. 47-61. 
Guerrot et al., 1989 C. Guerrot, J.-J. Peucat, R. Capdevila and L. Dosso, Archean protoliths within Early Proterozoic granulitic crust of the west European Hercynian belt: possible relics of the west African craton, Geology 17 (1989), pp. 241-244.

Guillot et al., 2002 F. Guillot, U. Schaltegger, J.M. Bertrand, E. Deloule and T. Baudin, Zircon U-Pb geochronology of Ordovician magmatism in the polycyclic Ruitor Massif (Internal W Alps), International Journal of Earth Sciences 91 (2002), pp. 964-978.

Guttiérrez-Alonso et al., 2003 G. Guttiérrez-Alonso, J. Fernández-Suárez, T.E. Jeffries, G.A. Jenner, M.N. Tubrett, R. Cox and S.E. Jackson, Terrane accretion and dispersal in the northern Gondwana margin. An Early Paleozoic analogue of a long-lived active margin, Tectonophysics 365 (2003), pp. 221-232.

Jegouzo et al., 1986 P. Jegouzo, J.-J. Peucat and C. Audren, Caractérisation et signification géodynamique des orthogneiss calco-alcalins d'âge ordovicien de Bretagne méridionale, Bulletin Société Géologique de France 5 (1986), pp. 839-848.

Keay and Lister, 2002 S. Keay and G. Lister, African provenance for the metasediments and metaigneous rocks of the Cyclades, Aegean Sea, Greece, Geology 30 (2002), pp. 235-238. Kröner and Layer, 1992 A. Kröner and P.W. Layer, Crust formation and plate motion in the Early Archean, Science 256 (1992), pp. 1405-1411.

Lafon, 1986 Lafon, J.-M., 1986. Géochronologie U-Pb appliquée à deux segments du Massif Central français. Le Rouergue oriental et le Limousin central. Ph.D. thesis, 1152pp., Univ. Montpellier.

Lahondére et al., 2004 D. Lahondére, D. Thiéblemont, J.C. Goujou, J. Le Métour, P. Barbey, G. Bronner, M. Deschamps, A. Cocherie, C. Guerrot and J. Marchand, Evolution archéenne à paléoprotérozoique de la Dorsale de Rgueïbat (Nord de la Mauritanie), 20th Coll. Afr. Geol., Orléans, Abstract (2004), p. 251.

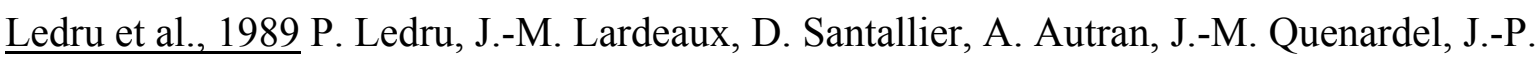
Floc'h, G. Lerouge, N. Maillet, J. Marchand and A. Ploquin, Où sont les nappes dans le massif central français?, Bulletin Société Géologique de France 5 (1989), pp. 605-618.

Lescuyer and Cocherie, 1992 J.-L. Lescuyer and A. Cocherie, Datation sur monozircons des métadacites de Sériès: arguments pour un âge protérozoique terminal des « schistes X » de la Montagne Noire (Massif Central français), Comptes Rendus Académie Sciences, Paris 314 (1992), pp. 1071-1077.

Lévêque, 1985 M.-H. Lévêque, Mise en évidence d'un témoin du socle précambrien dans le Massif Central français, Comptes Rendus Académie Sciences, Paris 300 (1985), pp. 277-281. 
Lévêque, 1990 Lévêque, M.-H., 1990. Contribution de la géochronologie U-Pb à la caractérisation du magmatisme cadomien de la partie sud-est du Massif Central et du gisement d'uranium associé de Bertholène. Ph.D. thesis, 249 p., Université Montpellier II.

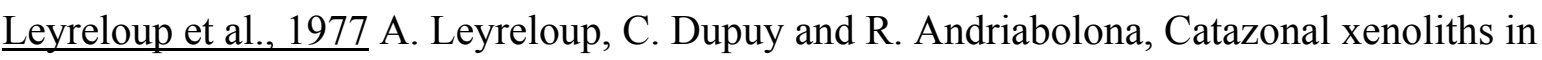
French Neogene volcanics rocks, Contributions to Mineralogy and Petrology 62 (1977), pp. 283-300.

Liew and Hofmann, 1988 T.C. Liew and A.W. Hofmann, Precambrian crustal components plutonic associations plate environment of the Hercynian Fold Belt of central Europe: Indications from a $\mathrm{Nd}$ and $\mathrm{Sr}$ isotopic study, Contribution to Mineralogy and Petrology 98 (1988), pp. 129-138.

Ludwig, 2004 Ludwig, K.R., 2004. Users manual for ISOPLOT/EX, version3.1. A geochronological toolkit for Microsoft Excel. Berkeley Geochronology Center, Special Publication, 4.

Malloe, 1982 S. Malloe, Petrogenesis of Archean tonalites, Geologisches Rundschau 71 (1982), pp. 328-346.

Mallard and Rogers, 1997 L.D. Mallard and J.J.W. Rogers, Relationship of Avalonian and Cadomian terranes to Grenville and Pan-African events, Journal of Geodynamics 23 (1997), pp. 197-221.

Matte, 1986 P. Matte, La chaîne Varisque parmi les chaînes paléozoïques péri-atlantiques, modèle d'évolution et position des grands blocs continentaux au Permien-Carbonifère, Bulletin Société Geologique de France 328 (1986), pp. 9-21.

Matte, 1991 P. Matte, Accretionary history and crustal evolution of the Variscan belt in western Europe, Tectonophysics 196 (1991), pp. 309-339.

Matte, 2001 P. Matte, The Variscan collage and orogeny (480-290 Ma) and the tectonic definition of the Armorica microplate: a review, Terra Nova 13 (2001), pp. 122-128. Medeiros Delgado et al., 2003 I. Medeiros Delgado, J.D. De Souza, L.C. Da Silva, N.C. Da Silveira Filho, R. Alves dos Santos, A.J. Pedreira, J. Torres Guimarães, L.A. De Aquino Angelim, A.M. Vasconcelos, I.P. Gomes, J.V. De Lacerda Filho and C.R. Valente, Geotectonics of the Atlantic Shield. In: L.A. Bizzi, C. Schobbenhaus, R.M. Vidotti and J.H. Gonçalves, Editors, Geologia, Tectônica e Recursos Minerais do Brasil, CPRM, Brasília (2003), pp. 227-334.

Micheletti et al., 2007 F. Micheletti, P. Barbey, A. Fornelli, G. Piccareta and E. Deloule, Latest Precambrian $\mathrm{U}-\mathrm{Pb}$ zircon ages of augen gneisses from Calabria (Italy), with inference 
to the Alboran microplate in the evolution of the peri-Gondwana terranes, International Journal of Earth Sciences 96 (2007), pp. 843-860.

Montero et al., 2007 P. Montero, F. Bea, F. González-Lodeiro, C. Talavera and M.J.

Whitehouse, Zircon ages of the metavolcanic rocks and metagranites of the Ollo de Sapo Domain in central Spain: implications for the Neoproterozoic to Early Paleozoic evolution of Iberia, Geology Magazine 144 (2007), pp. 1-14.

Murphy et al., 2006 J.B. Murphy, G. Guttiérrez-Alonso, R.D. Nance, J. Fernández-Suárez, J.D. Keppie, C. Quesada, R.A. Strachan and J. Dostal, Origin of the Rheic Ocean: rifting along a Neoproterozoic suture?, Journal of the Geological Society America 34 (2006), pp. $325-328$.

Neubauer, 2002 F. Neubauer, Evolution of late Neoproterozoic to early Paleozoic tectonic elements in Central and Southeast European Alpine mountain belts: review and synthesis, Tectonophysics 352 (2002), pp. 87-103.

Peucat et al., 1988 J.J. Peucat, P. Jegouzo, P. Vidal and J. Bernard Griffiths, Continental crust formation seen through the $\mathrm{Sr}$ and $\mathrm{Nd}$ isotopic systematics of S-type granites in the Hercynian belt of western France, Earth Planetary Sciences Letters 88 (1988), pp. 60-68.

Pin and Lancelot, 1978 C. Pin and J.R. Lancelot, Un exemple de magmatisme cambrien dans le massif central: les métadiorites quartziques intrusives dans la série du Lot, Bulletin Société Géologique de France 20 (1978), pp. 203-208.

Pin and Marini, 1993 C. Pin and F. Marini, Early Ordovician continental break-up in Variscan Europe: $\mathrm{Nd}-\mathrm{Sr}$ isotope and trace element evidence from bimodal igneous associations of Southern Massif Central, France, Lithos 29 (1993), pp. 177-196.

Ringwood, 1974 A.E. Ringwood, The petrological evolution of island-arc system, Journal of the Geological Society of London 130 (1974), pp. 183-204.

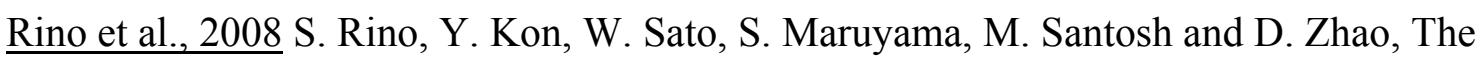
Grenvillian and Pan-African orogens: world's largest orogenies through geologic time, and their implications on the origin of superplume, Gondwana Research 14 (2008), pp. 51-72. Roger et al., 2004 F. Roger, J.-P. Respaut, M. Brunel, P. Matte and J.-L. Paquette, Première datation $\mathrm{U}-\mathrm{Pb}$ des orthogneiss oeillés de la zone axiale de la Montagne Noire (Sud du Massif Central): nouveaux témoins du magmatisme ordovicien dans la chaîne varisque, Comptes Rendus Géosciences 336 (2004), pp. 19-28.

$\underline{\text { Rossi et al., } 2006}$ P. Rossi, A. Cocherie, C.M. Fanning and E. Deloule, Variscan to eo-Alpine events recorded in European lower-crust zircons sampled from the French Massif Central and Corsica, France, Lithos 87 (2006), pp. 235-260. 


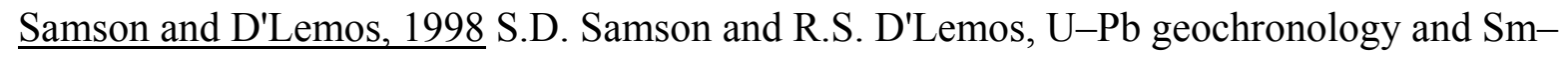
$\mathrm{Nd}$ isotopic composition of Proterozoic gneisses, Channel Islands, UK, Journal of the Geological Society (London) 155 (1998), pp. 609-618.

Santallier, 1981 Santallier, D., 1981. Les roches métamorphiques du Bas-Limousin, Massif Central (France). PhD thesis, Orléans (France), 340 pp.

Simien, 1998 Simien, F., 1998. Croissance crustale et contraintes paléogéographiques apportées par les isotopes du Nd dans les sédiments. Ph.D. thesis, 302 pp., Institut de Physique du Globe de Paris, Univ. Paris 7.

Stampfli et al., 2002 G.M. Stampfli, J.F. Von Raumer and G.D. Borel, Paleozoic evolution of pre-Variscan terranes: from Gondwana to the Variscan collision, Geological Society of America, special paper 364 (2002), pp. 263-280.

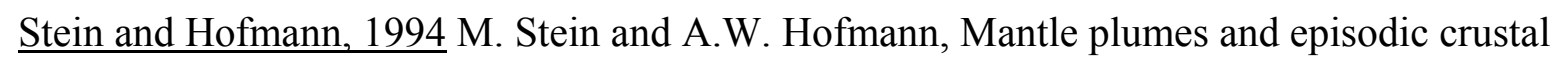
growth, Nature 372 (1994), pp. 63-68

Tera and Wasserburg, 1972 F. Tera and G.J. Wasserburg, U-Th-Pb systematics in three Apollo 14 basalts and the problem of initial $\mathrm{Pb}$ in lunar rocks, Earth Planetary Sciences Letters 14 (1972), pp. 281-304.

Villeuneuve et al., 2006 M. Villeuneuve, H. Bellon, A. El Archi, M. Sahabi, J.P. Rehault, J.L. Olivet and A.M. Aghzer, Evénements panafricains dans l'Adrar Souttouf (Sahara marocain), Comptes Rendus Geosciences 338 (2006), pp. 359-367.

Von Raumer and Stampfli, 2008 J.F. Von Raumer and G.M. Stampfli, The birth of the Rheic Ocean - Early Paleozoic subsidence patterns and subsequent tectonic plate scenarios, Tectonophysics 461 (2008), pp. 9-20 10.1016/j.tecto.2008.04.012

Von Raumer et al., 2002 J.F. Von Raumer, G.M. Stampfli, G. Borel and F. Bussy, Organization of pre-Variscan basement areas at the north-Gondwanan margin, International Journal of Earth Sciences 91 (2002), pp. 35-52.

Von Raumer et al., 2003 J.F. Von Raumer, G.M. Stampfli and F. Bussy, Gondwana-derived microcontinents - the constituents of the Variscan and Alpine collisional orogens,

Tectonophysics 365 (2003), pp. 7-22.

Watson, 1996 E.B. Watson, Dissolution, growth and survival of zircons during crustal fusion: kinetic principles, geological models and implications for isotopic inheritance, Transactions of the Royal Society of Edinburgh. Earth sciences 87 (1996), pp. 43-56

Wendt and Carl, 1991 I. Wendt and C. Carl, The statistical distribution of the mean squared weight deviation, Chemical Geology 86 (1991), pp. 275-285. 
Wiedenbeck et al., 1995 M. Wiedenbeck, P. Allé, F. Corfu, W.L. Griffin, M. Meier, F. Oberli, A. von Quadt, J.C. Roddick and W. Spiegel, Three natural zircon standards for U-Th-Pb, LuHf, trace element and REE analysis, Geostandards Newsletter 19 (1995), pp. 1-23

Ziegler, 1986 P.A. Ziegler, Geodynamic model for the palaeozoic crustal consolidation of Western and Central Europe, Tectonophysics 126 (1986), pp. 303-328. 


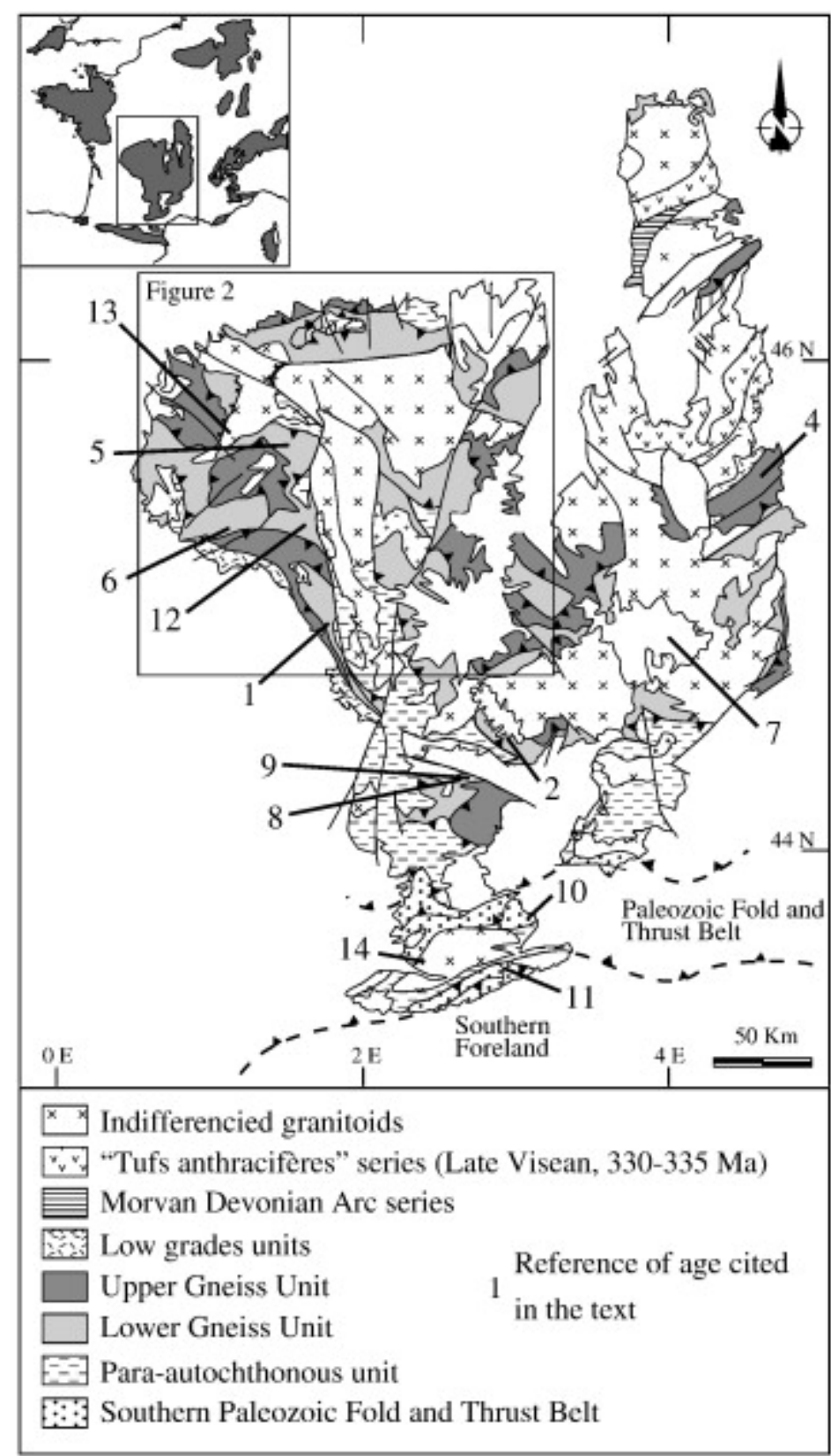

Fig. 1. General geological map of the French Massif Central with localizations of ages cited in the text (modified after Faure et al., 2005). 


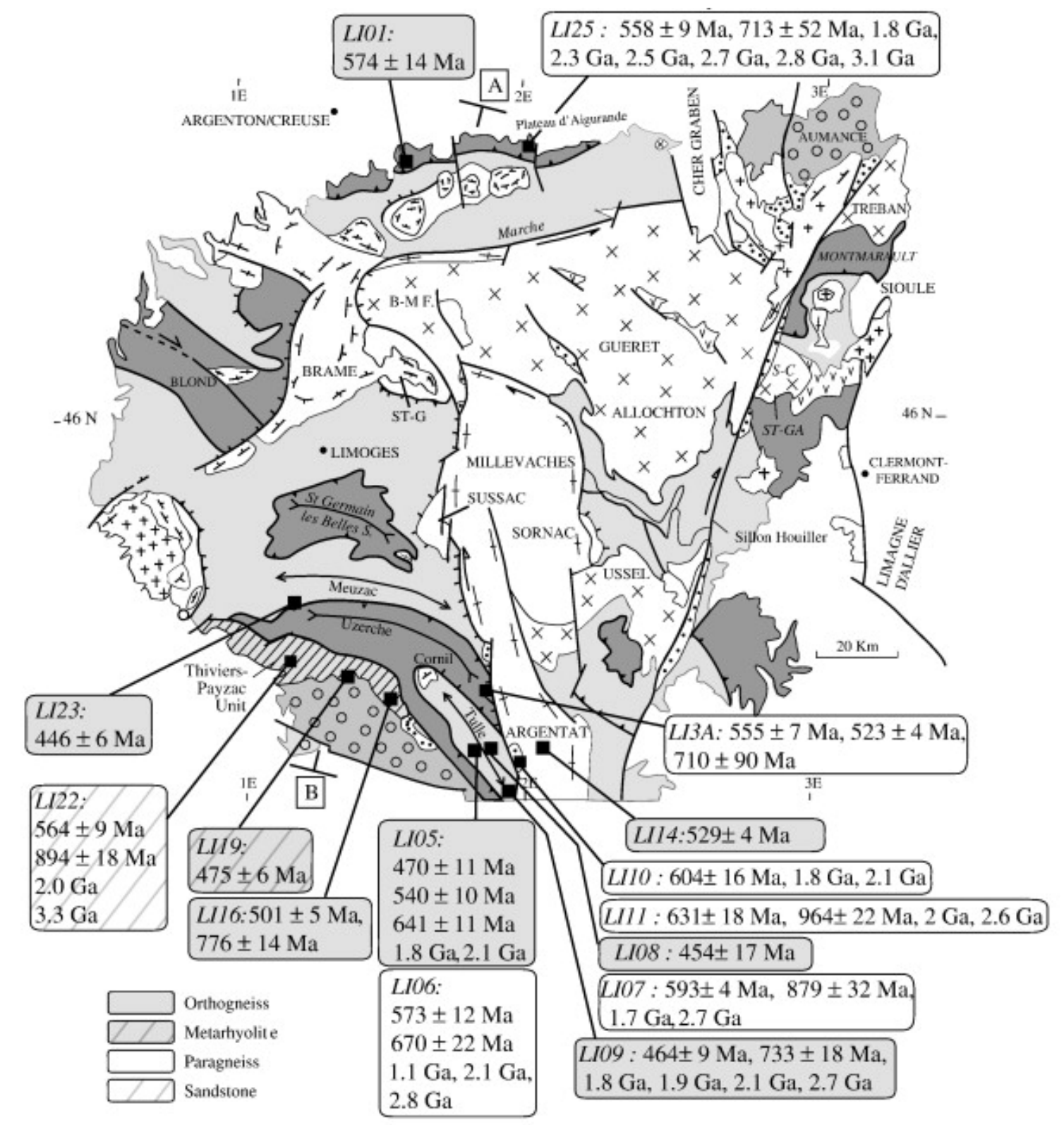

$0^{\circ}$ Permian deposits

\begin{tabular}{|c|c|c|}
\hline$\cdot \cdot$ Carboniferous deposits \\
\hline
\end{tabular}

$x /+$ Middle Carboniferous granitoids

$x+$ with foliation trend when known

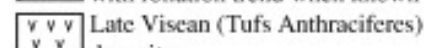
deposits

\begin{tabular}{l} 
Pre-late Visean granites (Gueret, \\
Ussel, Treban, St Gervais d'Auvergne) \\
Thiviers-Paysac Unit \\
Upper Gneiss Unit \\
$\square$ Metamorphic rocks of the Lower Gneiss Unit \\
\hline$\quad$ Para-autochthonous Unit (mainly micaschist)
\end{tabular}

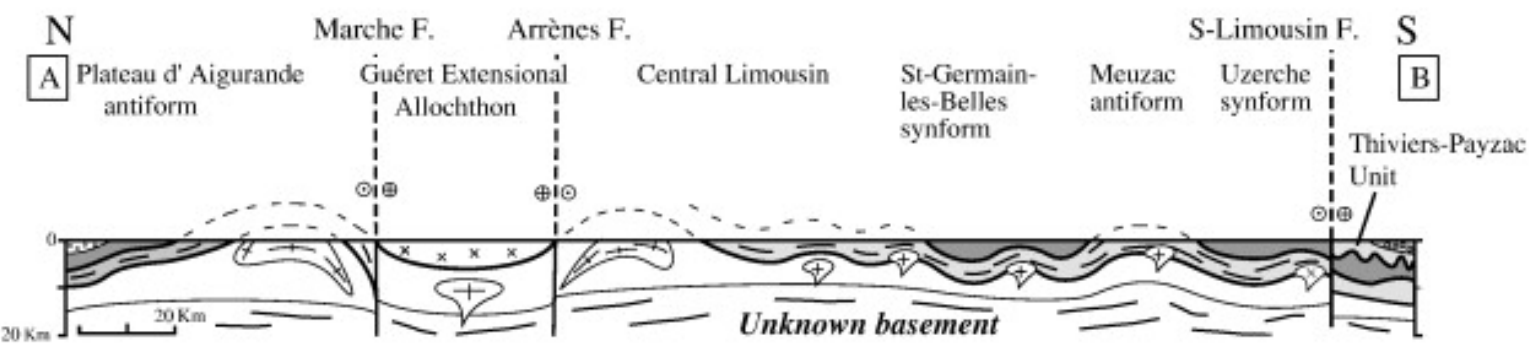

Fig. 2. Geological sketch map and N-S cross section of the Limousin area, and samples localizations. 

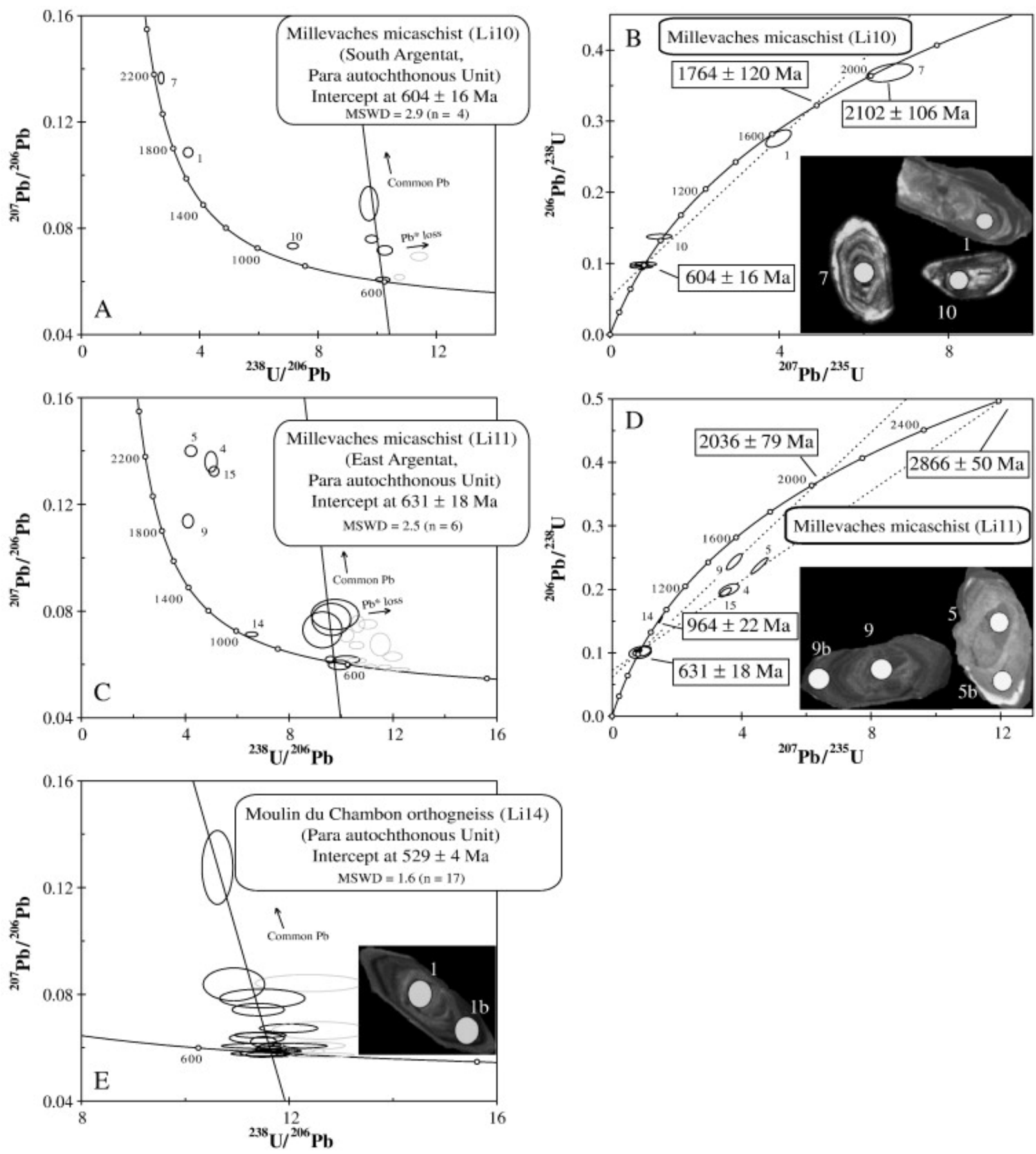

Fig. 3. Inverse (A, C, E) and normal (B, D) concordia diagrams reporting zircon $\mathrm{U}-\mathrm{Pb}$ data in samples of the Para-Autochthonous Unit. Examples of CL images of zircon are shown with location of analytical points. The diameter of ablation pit is ca. $20 \mu \mathrm{m}$. Data-point error ellipses are plotted as $2 \sigma$. 

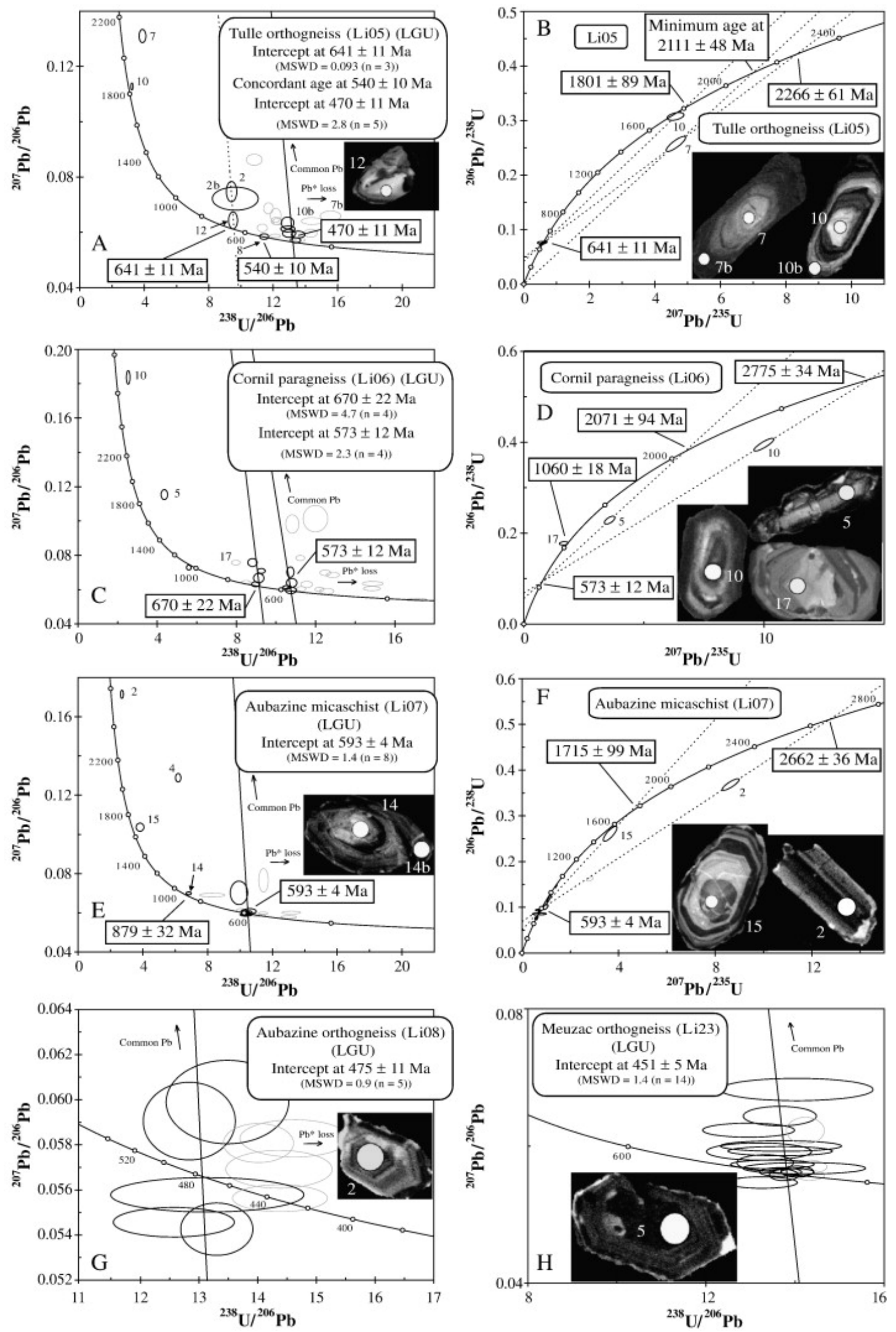

Fig. 4. Inverse (A, C, E, G, H) and normal (B, D, F) concordia diagrams reporting zircon U$\mathrm{Pb}$ data in samples of the Lower Gneiss Unit. Examples of CL images of zircon are shown with location of analytical points. The diameter of ablation pit is ca. $20 \mu \mathrm{m}$. Data-point error ellipses are plotted as $2 \sigma$. 

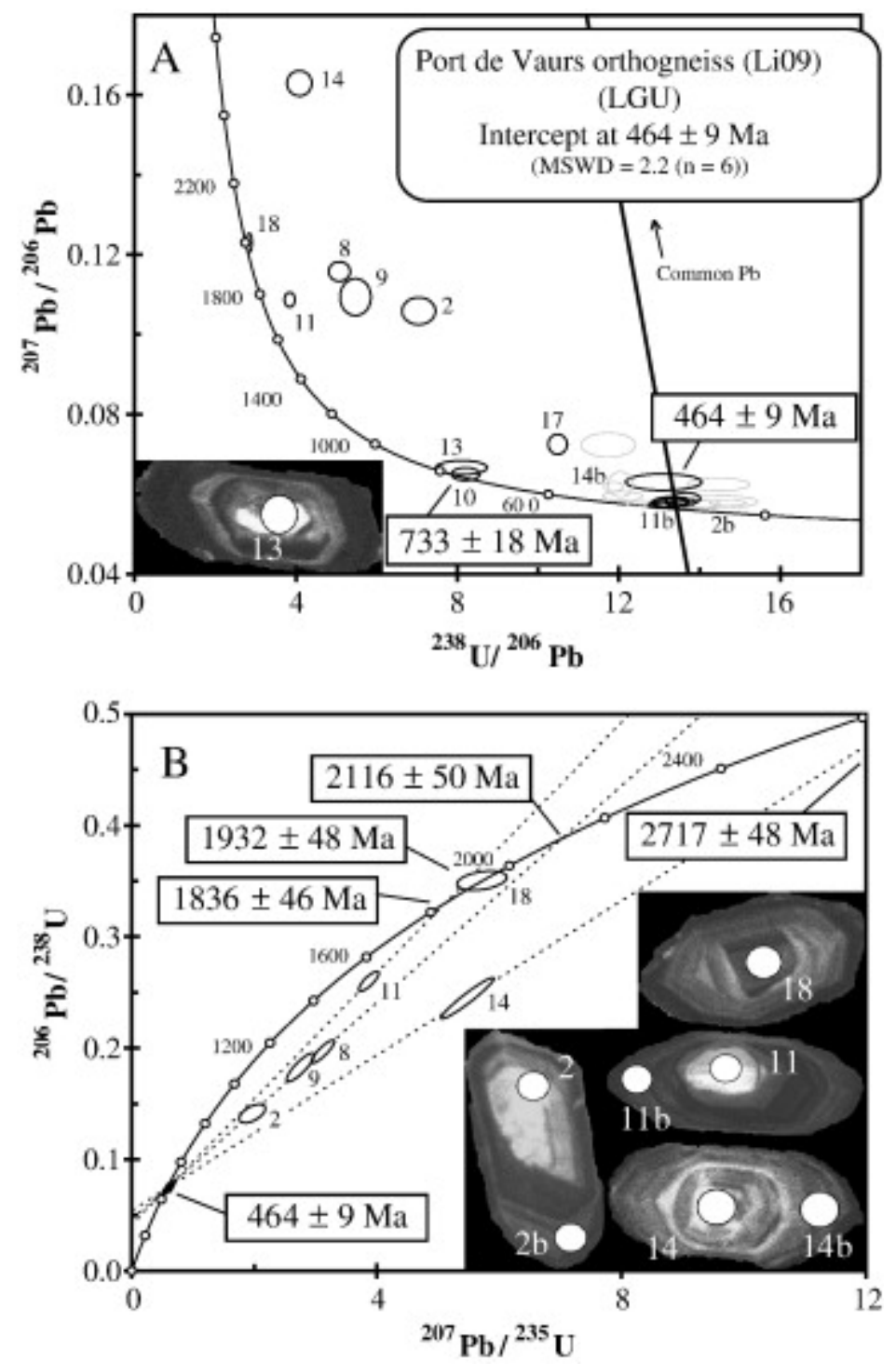

Fig. 5. Inverse (A) and normal (B) concordia diagrams reporting zircon $\mathrm{U}-\mathrm{Pb}$ data in samples of the Lower Gneiss Unit. Examples of CL images of zircon are shown with location of analytical points. The diameter of ablation pit is ca. $20 \mu \mathrm{m}$. Data-point error ellipses are plotted as $2 \sigma$. 

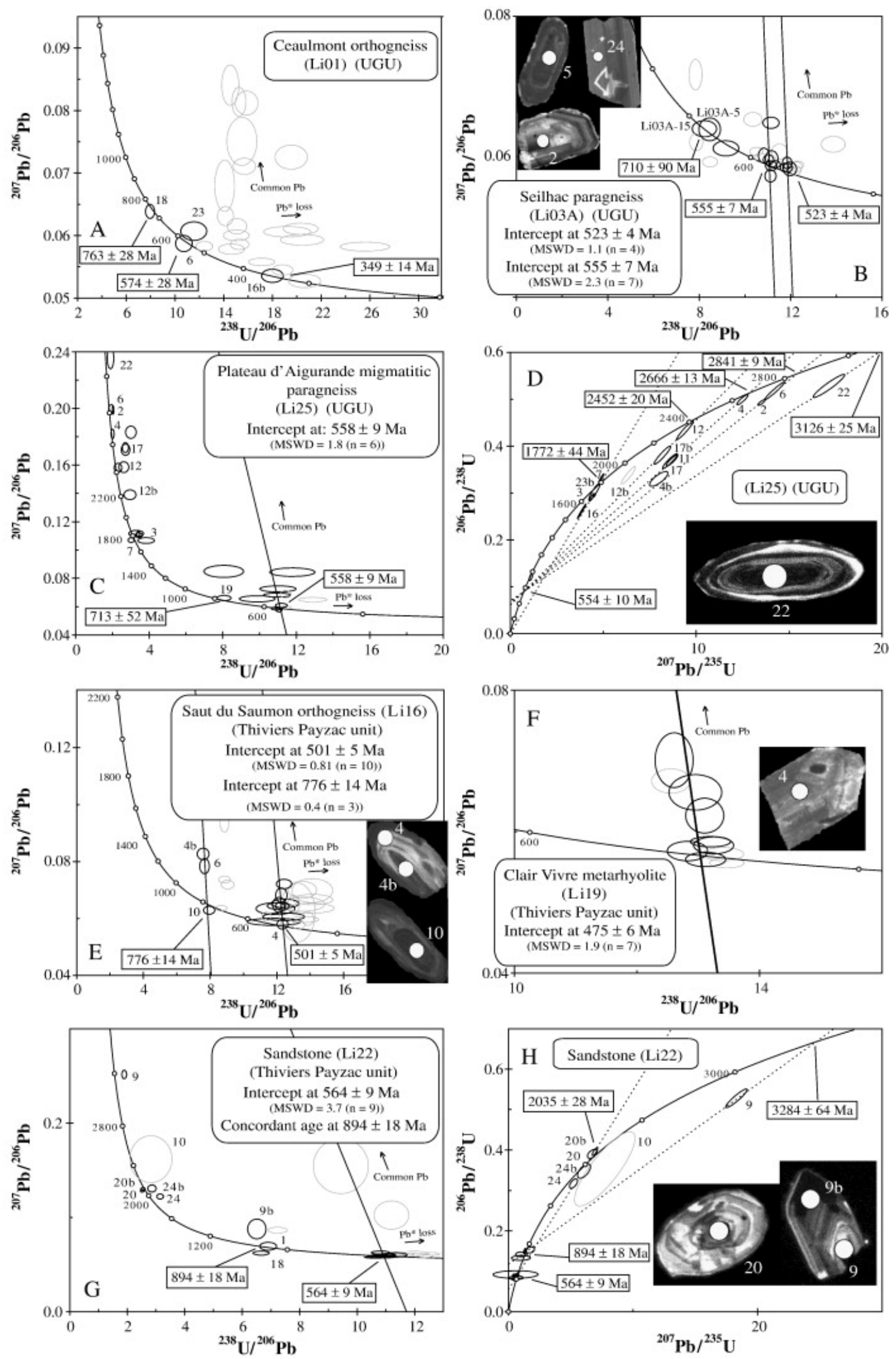

Fig. 6. Inverse (A, B, E, F, G) and normal $(\mathrm{D}, \mathrm{H})$ concordia diagrams reporting zircon $\mathrm{U}-\mathrm{Pb}$ data in samples of the Upper Gneiss Unit and Thiviers-Payzac Unit. Examples of CL images of zircon are shown with location of analytical points. The diameter of ablation pit is ca. $20 \mu \mathrm{m}$. Data-point error ellipses are plotted as $2 \sigma$. 
Magmatic rocks

Metasedimentary rocks

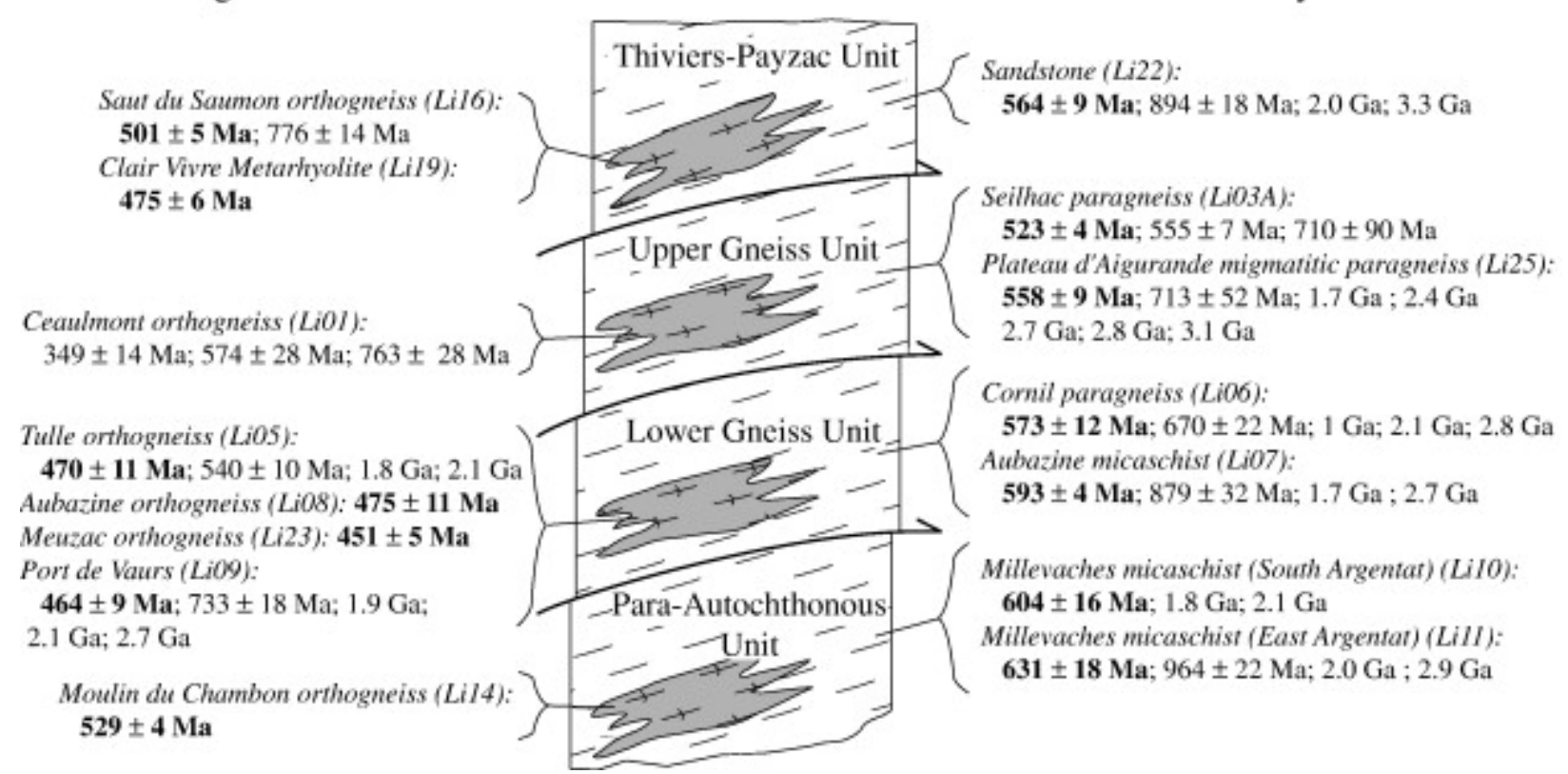

Fig. 7. Schematic diagram summarizing the various $\mathrm{U}-\mathrm{Pb}$ on zircon ages obtained in the different tectonostratigraphic units of the Limousin area. Bold ages are indicating the maximum deposition ages for the metasedimentary formations and magmatic emplacement ages for the orthogneiss

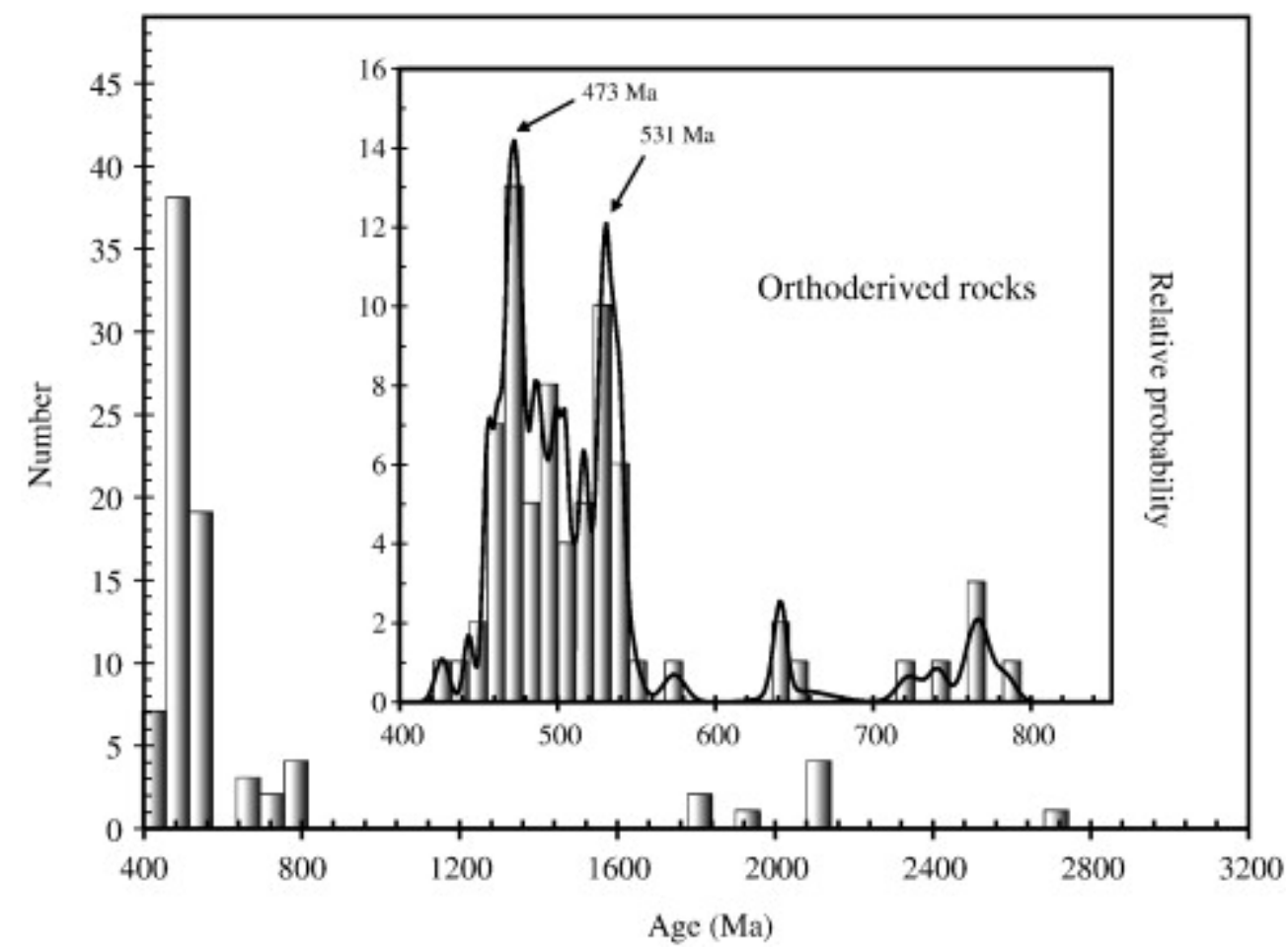

Fig. 8. Synthetic histogram of U-Pb on zircons ages and cumulative probability curve obtained in para-derived samples from the Limousin area. The higher histogram is focused on the period $1100-450 \mathrm{Ma}$. 


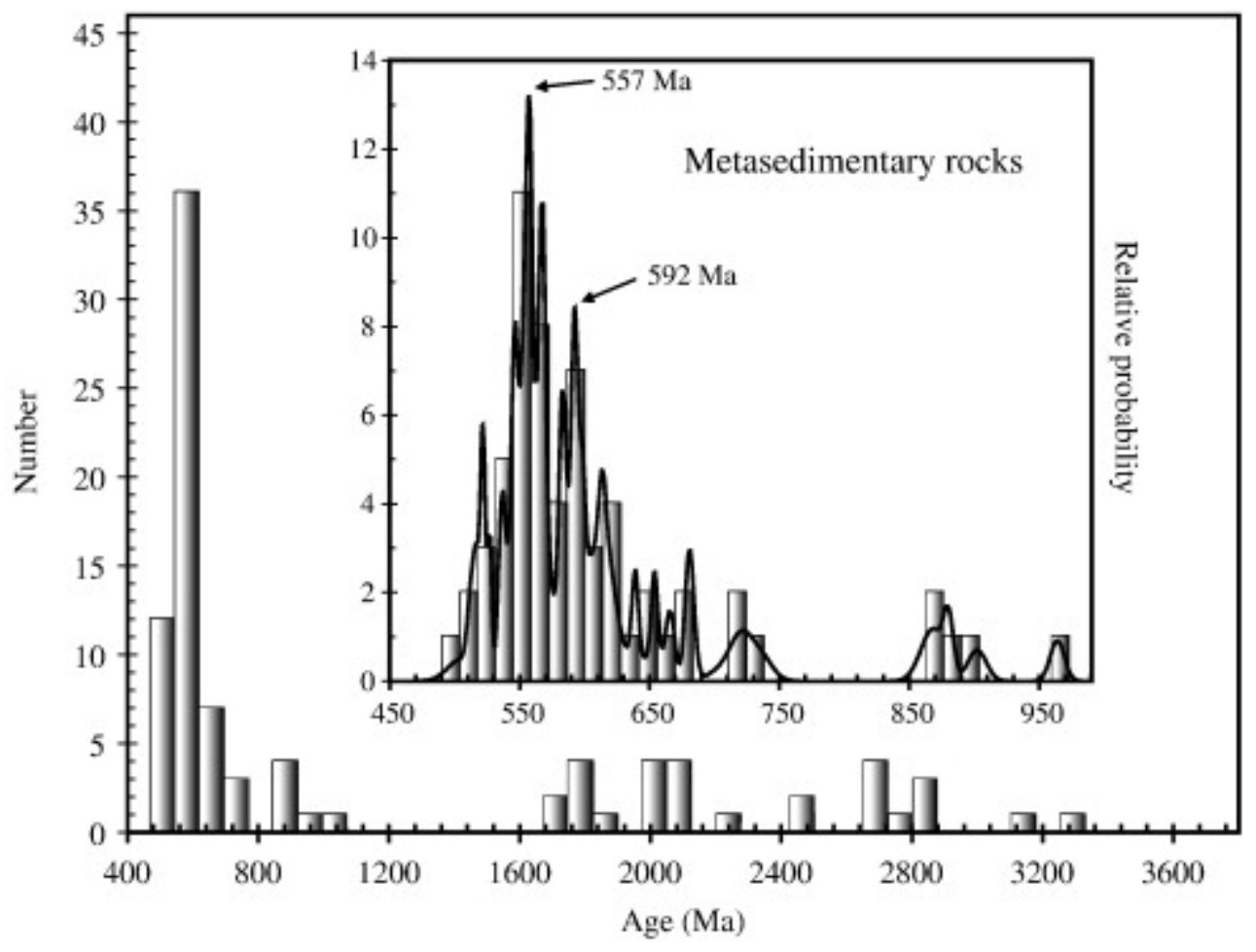

Fig. 9. Synthetic histogram of U-Pb on zircons ages and cumulative probability curve obtained in magmatic samples from the Limousin area. The higher histogram is focused on the period $850-400 \mathrm{Ma}$. 
Table 1. : Literature data of $\mathrm{U}-\mathrm{Pb}$ zircon ages of orthogneiss from the French Massif Central

\begin{tabular}{|c|c|c|c|c|}
\hline \multicolumn{2}{|c|}{ Location } & Ages (Ma) & Method & References \\
\hline \multicolumn{5}{|c|}{ Cambro-Ordovician magmatic ages } \\
\hline 1 & Vergonzac Orthogneiss (LGU) & $525 \pm 6$ & $\begin{array}{l}\mathrm{U}-\mathrm{Pb} \\
\text { SHRIMP }\end{array}$ & $\underline{\text { Alexandrov et al. }(2000)}$ \\
\hline 2 & Picades Diorite (LGU) & $540 \pm 15$ & U-Pb TIMS & $\underline{\text { Pin and Lancelot (1978) }}$ \\
\hline 3 & Aire de Côte Diorite (PU) & $500 \pm 16$ & U-Pb TIMS & $\underline{\text { Caron (1994) }}$ \\
\hline \multirow[t]{2}{*}{4} & $\begin{array}{l}\text { Mont du Lyonnais orthogneiss } \\
\text { (UGU) }\end{array}$ & $467 \pm 10$ & U-Pb TIMS & $\underline{\text { Feybesse et al. (1995) }}$ \\
\hline & & $466 \pm 9$ & & \\
\hline 5 & Sauviat Orthogneiss (LGU) & $\begin{array}{l}496+25- \\
17\end{array}$ & $\mathrm{U}-\mathrm{Pb}$ TIMS & $\underline{\text { Gebauer et al. (1981) }}$ \\
\hline 6 & Meuzac orthogneiss (LGU) & $495 \pm 8$ & U-Pb TIMS & $\underline{\text { Lafon }(1986)}$ \\
\hline 11 & Montagne Noire metadacite & $545 \pm 15$ & U-Pb TIMS & $\begin{array}{l}\text { Lescuyer and Cocherie } \\
\underline{(1992)}\end{array}$ \\
\hline \multicolumn{5}{|c|}{ Neoproterozoic } \\
\hline \multirow[t]{2}{*}{8} & $\begin{array}{l}\text { Caplongue and La Clau } \\
\text { granodiorites }\end{array}$ & $557 \pm 12$ & U-Pb TIMS & $\underline{\text { Lafon }(1986)}$ \\
\hline & & $600 \pm 30$ & & \\
\hline 9 & Palanges orthogneiss & $600 \pm 10$ & U-Pb TIMS & Lévêque (1985) \\
\hline 10 & Mendic orthogneiss & $608 \pm 10$ & U-Pb TIMS & Lévêque (1990) \\
\hline \multicolumn{5}{|c|}{ Paleoproterozoic and Archean } \\
\hline \multirow[t]{2}{*}{9} & $\begin{array}{l}\text { Palanges formation and Mendic } \\
\text { granite }\end{array}$ & $1.87 \mathrm{Ga}$ & U-Pb TIMS & Lévêque (1990) \\
\hline & & $1230 \pm 100$ & & \\
\hline 11 & Montagne Noire metadacite & $2.83 \mathrm{Ga}$ & $\mathrm{U}-\mathrm{Pb}$ TIMS & $\begin{array}{l}\text { Lescuyer and Cocherie } \\
\underline{(1992)}\end{array}$ \\
\hline 12 & La Flotte gabbro & $2.89 \mathrm{Ga}$ & U-Pb TIMS & $\underline{\text { Lafon }(1986)}$ \\
\hline 13 & Blond granite & $1.9 \mathrm{Ga}$ & $\begin{array}{l}\text { U-Pb } \\
\text { SHRIMP }\end{array}$ & Alexandrov et al. (2000) \\
\hline
\end{tabular}


Table 2. : Localization and lithological nature of the studied samples

\begin{tabular}{|c|c|c|c|}
\hline Sample number & $X$ & $\boldsymbol{Y}$ & Lithology \\
\hline \multicolumn{4}{|c|}{ Para-Autochthonous Unit } \\
\hline Li10 & E $1^{\circ} 57,291^{\prime}$ & $\mathrm{N} 45^{\circ} 04,838^{\prime}$ & Micaschist \\
\hline Li11 & E $1^{\circ} 57,257^{\prime}$ & $\mathrm{N} 45^{\circ} 06,333$ & Micaschist \\
\hline Li14 & E $2^{\circ} 03,306^{\prime}$ & $\mathrm{N} 45^{\circ} 05,145^{\prime}$ & Orthogneiss \\
\hline \multicolumn{4}{|l|}{ Lower Gneiss Unit } \\
\hline Li05 & E $1^{\circ} 43,213^{\prime}$ & $\mathrm{N} 45^{\circ} 13,871^{\prime}$ & Orthogneiss \\
\hline Li06 & E $1^{\circ} 43,213^{\prime}$ & $\mathrm{N} 45^{\circ} 13,871^{\prime}$ & Paragneiss \\
\hline Li07 & E $1^{\circ} 43,238^{\prime}$ & $\mathrm{N} 45^{\circ} 13,968^{\prime}$ & Micaschist \\
\hline Li08 & E $1^{\circ} 43,238^{\prime}$ & $\mathrm{N} 45^{\circ} 13,968^{\prime}$ & Orthogneiss \\
\hline Li09 & E $1^{\circ} 53,407^{\prime}$ & $\mathrm{N} 45^{\circ} 02,846^{\prime}$ & Orthogneiss \\
\hline $\mathrm{Li} 23$ & E $1^{\circ} 26,378^{\prime}$ & $\mathrm{N} 45^{\circ} 24,022^{\prime}$ & Orthogneiss \\
\hline \multicolumn{4}{|l|}{ Upper Gneiss Unit } \\
\hline Li01 & E $1^{\circ} 34,910^{\prime}$ & $\mathrm{N} 46^{\circ} 31,608^{\prime}$ & Orthogneiss \\
\hline Li03A & E $1^{\circ} 43,401^{\prime}$ & $\mathrm{N} 45^{\circ} 21,380^{\prime}$ & Paragneiss \\
\hline $\operatorname{Li} 25$ & E $1^{\circ} 55,841^{\prime}$ & $\mathrm{N} 46^{\circ} 32,052^{\prime}$ & Paragneiss \\
\hline \multicolumn{4}{|c|}{ Thiviers-Payzac Unit } \\
\hline Li16 & E $1^{\circ} 28,407^{\prime}$ & $\mathrm{N} 45^{\circ} 17,019^{\prime}$ & Orthogneiss \\
\hline Li19 & E $1^{\circ} 13,757^{\prime}$ & $\mathrm{N} 45^{\circ} 19,011^{\prime}$ & Metarhyolite \\
\hline $\mathrm{Li} 22$ & $\mathrm{E} 1^{\circ} 13,740^{\prime}$ & $\mathrm{N} 45^{\circ} 24,022^{\prime}$ & Metasandstone \\
\hline
\end{tabular}

